\title{
Observations of the 9 June 2002 Dryline During IHOP
}

\author{
Huaqing $\mathrm{Cai}^{*}$ and Wen-Chau Lee
}

National Center for Atmospheric Research ${ }^{\S}$, Boulder, Colorado, USA

\begin{abstract}
Detailed studies of drylines that do not initiate storms are rare but scientifically important. Studying these null cases will improve the understanding of critical factors separating whether convection would be initiated along a dryline. This observational study presents a null case dryline near the Oklahoma/New Mexico border during the International $\mathrm{H}_{2} \mathrm{O}$ Project (IHOP_2002) on 9 June 2002. High-resolution observations obtained from an airborne Doppler radar (ELDORA), two water-vapor Differential Absorption Lidar (LEANDRE II and LASE), Learjet dropsondes, as well as aircraft in situ measurements were used to describe the dryline environment and mesoscale structures in both along- and cross-line directions. The 9 June dryline was characterized by a rather broad radar reflectivity thinline with a large moisture gradient. Its updrafts were found generally associated with the local maximum of radar reflectivity; however, they were not colocated. The simultaneous observations from ELDORA and LEANDRE II confirmed that the dryline updrafts tend to be located near its moisture gradient, consistent with previous findings using aircraft in situ measurements.
\end{abstract}

The dryline moisture boundary was found to be greatly modified by mesocyclone circulations, which caused the alongline moisture gradient at certain segments of the dryline to become greater than the cross-line moisture gradient. Twodimensional water vapor fields derived from LEANDRE II across the dryline clearly showed the moisture gradient associated with the dryline and moisture variations on the order of $\sim 1 \mathrm{~g} \mathrm{~kg}^{-1}$ on both sides of the dryline. No storms initiated within the IHOP_2002 domain associated with this dryline owing to unfavorable atmospheric instability conditions and only weak upward forcing near the dryline.

Keywords: Dryline, convection initiation, IHOP.

\section{INTRODUCTION}

A dryline is a relatively common feature that occurs $\sim 32 \%$ of the time over the Great Plains in late spring and early summertime [1] and plays an important role in warm season convection initiation. A number of field campaigns and numerous studies have investigated the kinematic and thermodynamic structures of drylines using various observational tools such as surface mesonets, mobile soundings, aircraft in situ measurements [2-6]), Doppler lidar [7], ground-based mobile Doppler radars [8-10]) and airborne Doppler radar [11-14]). These aforementioned studies mostly documented drylines that initiated convection. In order to fully understand convection initiation along drylines, detailed observational study of drylines that do not initiate convection (the so-called "null" cases) is required. In fact, observational studies on "null" cases have been rare $[10,11,15-18])$. Scientifically and operationally, it is equally important to understand what may be the limiting factors to inhibit convection initiation along a dryline.

The focus of this paper is to document a null case dryline that occurred during the International $\mathrm{H}_{2} \mathrm{O}$ Project

\footnotetext{
*Address correspondence to this author at the National Center for Atmospheric Research, 3450 Mitchell Lane, Boulder, CO 80301, USA; Tel: 303-497-2876; Fax: 303-497-8401;

E-mail: caihq@ucar.edu

${ }^{\S}$ The National Center for Atmospheric Research is sponsored by the National Science Foundation.
}

(IHOP_2002 [18]) on 9 June 2002 using data collected by the Natioanl Science Foundation Electra Doppler Radar (ELDORA) [19, 20]), water-vapor Differential Absorption Lidar (DIAL) LEANDRE II (Lidar pour l'Etude des interactions Aérosols Nuages Dynamique Rayonnement et du cycle de l'Eau, i.e., Lidar for the study of Aerosol-CloudDynamics-Radiation interactions and of the water cycle [21], the Lidar Atmospheric Sensing Experiment [LASE, 22], Learjet dropsondes, as well as the Naval Research Laboratory (NRL) P3 flight-level data. Throughout this case study paper, however, comparisons between this dryline and other IHOP drylines that initiated or did not initiate storms will be made when necessary. For detailed comparative studies of general features of some IHOP drylines, the reader is referred to Wakimoto and Murphey [14] and Miao and Geets [17].

The analyses of the 9 June dryline is special in the following aspects compared with previous dryline studies: 1) this segment of the dryline was among the weakest in the dryline spectrum in terms of water vapor mixing ratio difference across the dryline, maximum updrafts near the dryline convergence boundary, and maximum vertical vorticities associated with the misocyclones near the dryline; however, the moisture gradient associated with this dryline could be as large as $\sim 1 \mathrm{~g} \mathrm{~kg}^{-1} \mathrm{~km}^{-1}$ as a result of narrow dryline mixing zone width of $\sim 1.2 \mathrm{~km} ; 2$ ) simultaneous observations of a dryline by a Doppler radar (i.e., ELDORA) and two water vapor DIAL (i.e., LEANDRE II and LASE) are rare. To the authors' knowledge, only two such analyses exist in the literature $[15,23]$, all of them used IHOP_2002 
datasets; and finally, 3) case studies of drylines that did not initiate storms are relatively rare in the literature $[8,10,11$, $15-17,24]$; this paper addresses one of the IHOP_2002 objectives: to measure three-dimensional water vapor fields using the state-of-the-art remote sensing tools available to study important forecasting issues such as warm season convection initiation.

Section 2 briefly describes the IHOP_2002 field project and the data processing methodology used in this paper. Detailed structure of the 9 June dryline is presented in section 3 as revealed by ELDORA, LEANDRE II, LASE, Learjet dropsondes, and NRL-P3 in situ measurements. A summary and discussion are given in section 4 .

\section{IHOP_2002 AND DATA METHODOLOGY}

IHOP_2002 was a multiagency international field campaign conducted over the southern Great Plains in spring and early summer of 2002. The primary goal of IHOP_2002 was to better understand the role of water vapor in various atmospheric processes, including convection initiation. A number of the state-of-the-art remote sensing tools, both ground-based and airborne, were deployed during the field campaign. Previously unavailable high spatial and temporal resolution data were collected. For a detailed description of IHOP_2002, the reader is referred to Weckwerth et al. [18]. The primary instruments used in this study and their data processing approaches are discussed below.

\subsection{ELDORA}

ELDORA is an X-band tail Doppler radar mounted on the NRL P3 aircraft and operated by the National Center for Atmospheric Research (NCAR). Owing to its high sensitivity (-12 $\mathrm{dBZ}_{\mathrm{e}}$ at $10 \mathrm{~km}$ range), ELDORA has been successfully used in a number of studies to document clearair convergence boundaries $[11,12,25])$. For the details of ELDORA, the reader is referred to Hildebrand, et al. [19].

Similar to previous studies using ELDORA data, the radar data processing starts with a careful navigation correction procedure [26, 27]). Each radar sweep was manually edited using the NCAR SOLO software [28] to remove spurious echoes. The fore and aft radar data were interpolated to a Cartesian grid using the NCAR REORDER software. Based on the along-track resolution of 600 $\mathrm{m}$ [23] for ELDORA scanning parameters during IHOP_2002 and the maximum dimension of radar sampling volume of $\sim 370$ $\mathrm{m}$ at a range of $12 \mathrm{~km}$ with a beam width of $1.8^{\circ}$ (no dualDoppler analysis beyond $\sim 12 \mathrm{~km}$ was attempted), the horizontal and vertical grid spacing are set to $600 \mathrm{~m}$ and 300 $\mathrm{m}$, respectively. According to Carbone et al. [29], only features with wavelengths greater than $3.6 \mathrm{~km}$ are fully resolvable in this study. A Cressman [30] filter was applied in the interpolation process with a radius of influence of 600 $\mathrm{m}$ in the horizontal and $300 \mathrm{~m}$ in the vertical direction. Custom Editing and Display of Reduced Information in Cartesian space (CEDRIC; [31]) were used to synthesize the dual-Doppler winds, and a 2-step Leise filter (Leise [32]) was applied to the derived wind field. Vertical velocity was obtained by upward integration of the continuity equation. This very same dual-Doppler analysis technique has been employed in a number of ELDORA studies [11, 15, 23]. For accuracy of ELDORA dual-Doppler synthesis, the reader is referred to Wakimoto and Cai [33].

\subsection{LEANDRE II}

LEANDRE II is a water-vapor DIAL developed at the Service d'Aéronomie (Centre National de la Recherche Scientifique -CNRS) in cooperation with the Technical Division of the Institut National des Sciences de l'Univers (INSU) and was funded by the Centre National d'Etudes Spatiales (CNES). The design of the LEANDRE II system and the standard DIAL signal processing are discussed in detail in Bruneau et al. [21].

LEANDRE II was mounted on the same aircraft (NRLP3) as ELDORA during IHOP_2002. The lidar was pointing horizontally out of the right side of the aircraft during all the convection initiation missions. LEANDRE II has an alongbeam resolution of $\sim 300 \mathrm{~m}$ and a water vapor mixing ratio measurement precision better than $0.5 \mathrm{~g} \mathrm{~kg}^{-1}$ in the $0-5 \mathrm{~km}$ distance range from the aircraft in the horizontal pointing mode [21]. Because of the saturation of lidar signal caused by high water vapor content in the convective boundary layer and the geometric factor of the lidar system, the usable lidar water vapor measurements only exist between 1.2 and 3.5-4 $\mathrm{km}$ along the lidar line of sight. For detailed discussion of the configuration and characteristics of LEANDRE II during IHOP_2002, please refer to Murphey et al. [23].

Following the same lidar data processing technique described in Murphey et al. [23] and Cai et al. [15], a twopass Barnes [34] filter was used to interpolate the lidar water vapor data onto the same Cartesian grid that was used for ELDORA dual-Doppler synthesis. The cutoff radius, the smoothing parameter, and the convergence parameter were set to $600 \mathrm{~m}, 600 \mathrm{~m}^{2}$, and 0.3 , respectively. These parameters were chosen to ensure that the spatial scale of the moisture field was comparable to that of the ELDORA dual-Doppler synthesis. Since no quantitative analyses were performed on the ELDORA and LEANDRE II derived fields, using different interpolating scheme such as the Cressman [30] filter in ELDORA analysis and the Barnes [34] filter in LEANDRE II analysis will not have much impact on the conclusions of this paper, thus the choice of different interpolating scheme is more of a personal preference in this case.

\subsection{LASE}

The Lidar Atmospheric Sensing Experiment (LASE) is a water vapor DIAL system that was developed and operated by the National Aeronautics and Space Administration (NASA) Langley Research Center. The lidar was mounted on the NASA DC-8 aircraft in a vertically downwardpointing mode during IHOP_2002 [22]. The LASE system is able to measure water vapor mixing ratio with an accuracy of better than $6 \%$ or $0.01 \mathrm{~g} \mathrm{~kg}^{-1}$, whichever is larger, across the troposphere [22]. During IHOP_2002, the LASE water vapor measurement had a vertical resolution of $330 \mathrm{~m}$ and a horizontal resolution of $\sim 14 \mathrm{~km}$ [35]. For details of the LASE system, the reader is referred to Browell et al. [22]. 


\subsection{NRL P3 Flight-Level Data}

The NRL P3 was equipped with in situ instruments installed by NCAR to measure atmospheric state variables as well as aircraft location, speed and heading information at 1 $\mathrm{Hz}$ frequency. The aircraft in situ measurements have been widely used in numerous previous dryline studies (e.g., [3, 11, 23]). For details of the data quality and accuracy of the NCAR-installed in situ instruments on NRL-P3, the reader is referred to http://www.eol.ucar.edu/raf/Bulletins/bulletin9.html.

It should be pointed out that throughout this paper, all the horizontal cross-sections of ELDORA analysis are set at the NRL-P3 flight level (i.e., $0.8 \mathrm{~km} \mathrm{AGL}$ ), which is also the height of the two-dimensional LEANDRE II water vapor measurement. Therefore, all horizontal measurements analyzed in this paper can be regarded as taking at the flight level.

\section{DETAILED STRUCTURE OF THE 9 JUNE 2002 DRYLINE}

\subsection{Environmental Conditions and Flight Tracks}

Subjective analyses of surface dryline position superimposed on visible satellite imagery at 2100 and 2200 UTC (hereafter, all times are UTC; Local time $=$ UTC $-5 \mathrm{hr}$ ) covering the IHOP_2002 domain are shown in Fig. (1). A well-defined dryline can be seen extending from Colorado through the Oklahoma panhandle, the Texas panhandle, and all the way into New Mexico, as indicated by a large dewpoint gradient across the dryline boundary. The Intensive Observation Region (IOR), which is defined by the box pattern flown by the NRL-P3 aircraft, was located near the Oklahoma/New Mexico border (the black box in Fig. 1a) for this mission. Flight tracks of the NRL-P3, NASA DC-8, and Learjet are shown in Fig. (2). Convection did not occur within the IOR along the dryline because of weak forcing

(a) 2100

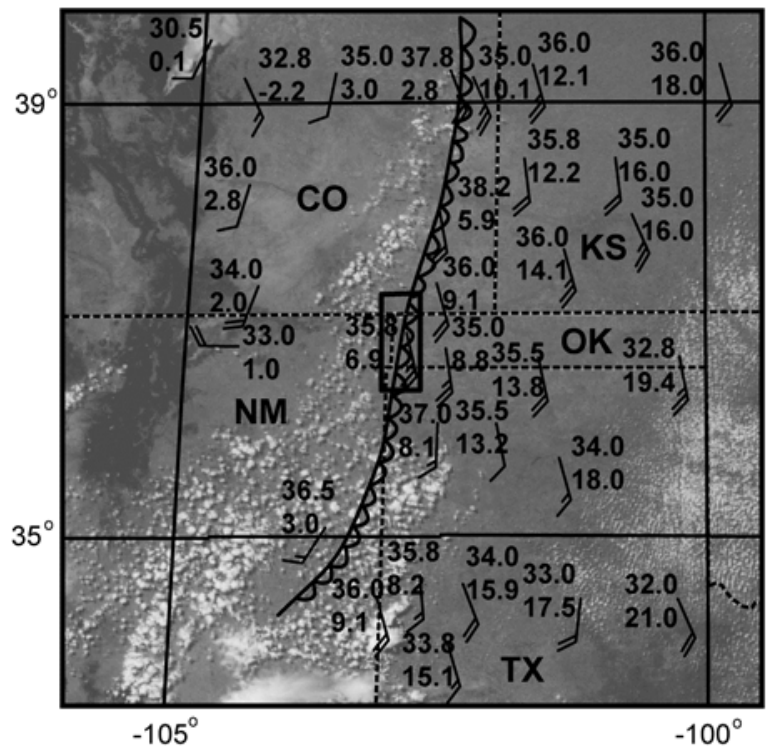

and unfavorable atmospheric instability conditions, which will be discussed in detail later on. Nonetheless, storms did form ahead of the dryline in the cool moist airmass farther south near the central Texas panhandle, which was well outside the IHOP_2002 domain (Fig. 1b).

\subsection{Horizontal Along-Line Variability}

Two north-south oriented long NRL-P3 flight legs along the dryline (i.e., 2102:33-2112:35 and 2120:04-2134:04) and two east-west oriented short legs across the dryline (i.e., 2115:33-2116:51 and 2138:03-2140:25) made up a clockwise box pattern near the Oklahoma/New Mexico border covering the 9 June 2002 dryline for a time period of $\sim 38 \mathrm{~min}$. The dryline was quasi-stationary during the same time period; therefore, ground-relative winds are the same as dryline-relative winds in this paper. ELDORA dual-Doppler synthesis, LEANDRE II and LASE water vapor DIAL measurements, Learjet dropsondes, as well as NRL-P3 in situ data are the primary datasets used for this case study. Throughout this paper we define along-line (cross-line) direction as the overall direction parallel (perpendicular) to the dryline reflectivity thinline inside the IOR. According to this definition, the along-line direction for the 9 June dryline is approximately north/south, as shown in Fig. (3).

Horizontal cross-sections of the 9 June 2002 dryline showed significant along-line variability (Fig. 3a). The radar reflectivity signature of clear-air boundaries such as drylines is usually called a "thinline" in the literature; however, the width of the thinlines could vary considerably from case to case. For the purpose of comparing dryline thinline width in different cases, a radar reflectivity threshold has to be chosen. Hereafter in this paper, a dryline thinline width is defined by the width of the region enclosed by the zero $\mathrm{dBZ}_{\mathrm{e}}$ radar reflectivity contours. The zero $\mathrm{dBZ}_{\mathrm{e}}$ threshold ensures that the echoes are clear-air returns, however, the value itself (b) 2200

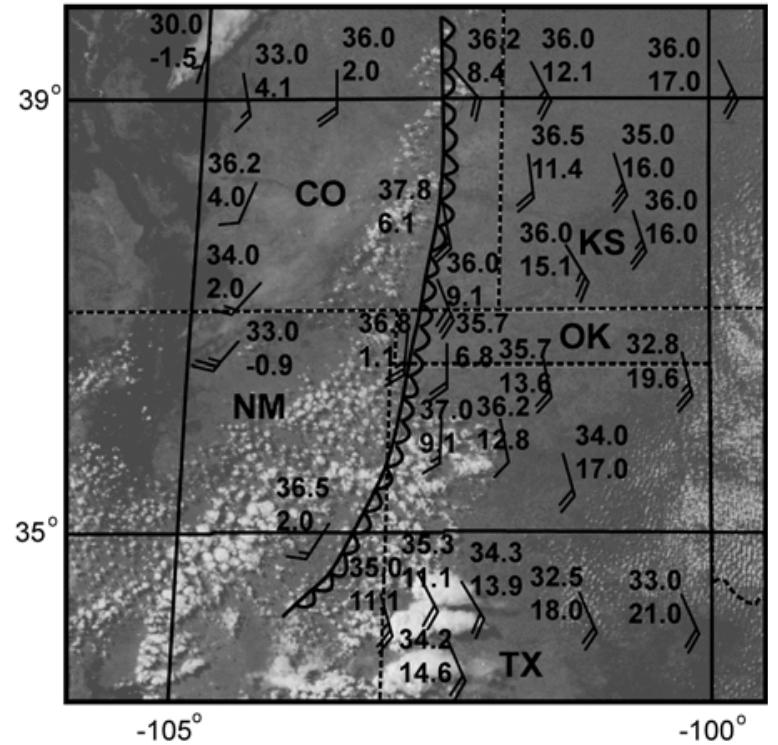

Fig. (1). Subjective surface dryline position analysis superimposed onto visible satellite images at (a) 2100 and (b) 2200 UTC on 9 June 2002. Temperature and dewpoint temperature are shown $\left({ }^{\circ} \mathrm{C}\right)$. Wind vectors are plotted with full barb and half barb representing 5 and $2.5 \mathrm{~m}$ $\mathrm{s}^{-1}$, respectively. Dotted lines are state lines. The black box in (a) represents the approximate dimension and location of the ELDORA analysis domain used in Figs. $(\mathbf{3}, \mathbf{5})$. 
is arbitrary, since there is no X-band radar reflectivity threshold existing in the literature which is used to define and compare dryline thinline width. It should be emphasized that the dryline thinline width is solely based on its radar reflectivity signature at $\mathrm{X}$ band, therefore, by definition, the thinline width has no relation to the dryline mixing zone width, which is defined by the dryline moisture gradient.

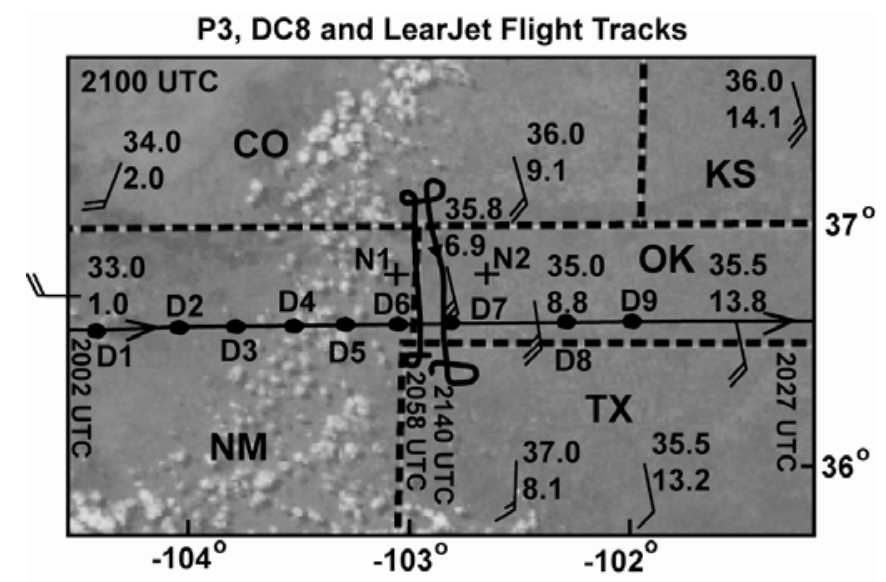

Fig. (2). NRL-P3 (thick black line), NASA DC-8 and Learjet (thin black line) flight tracks superimposed onto surface data and visible satellite image at 2100 UTC. Each individual drops by Learjet is denoted by a black dot (D1-D9). Mobile soundings are represented by plus signs (N1 and N2). All other symbols are the same as Fig. (1).

Wakimoto and Murphey [14] compared six drylines from IHOP_2002 and their results showed that the width of dryline thinlines as estimated from the zero $\mathrm{dBZ}_{\mathrm{e}}$ radar reflectivity contour from their Fig. (5) has a range between $\sim 4--\sim 18 \mathrm{~km}$, with most of drylines having a width less than $\sim 8 \mathrm{~km}$. The width of the 9 June 2002 dryline thinline (mostly greater than $10 \mathrm{~km}$ ) was on the broader side of the dryline thinline width spectrum, as suggested by Fig. (3a). A possible explanation for why some dryline thinlines are wider than the others is that wider thinline widths are caused by wider updrafts. However, a careful inspection of Fig. (3a), as well as results showed by Wakimoto and Murphey [14], seems to suggest that the thinline width is not always correlated with the updraft width. As a matter of fact, the dryline thinline width decreased in Fig. (5a) compared with Fig. (3a), but the updrafts seem more elongated in the crossline direction in Fig. (5a).

Both vertical vorticity $\left(<\sim 3 \mathrm{~s}^{-1}\right)$ and vertical velocity $(<$ $\sim 3 \mathrm{~m} \mathrm{~s}^{-1}$ ) associated with the 9 June dryline were relatively weak compared with other drylines during IHOP_2002 (e.g., $[14,17])$. Periodic updraft maxima in the along-line direction at intervals of $\sim 10-15 \mathrm{~km}$ can be seen in Fig. (3a), which is a feature that has been documented by previous studies for some drylines (e.g., [11, 15]). Atkins et al. [11] showed evidence that the periodic updrafts along the dryline in their case were caused by horizontal convective rolls intercepting the dryline; however, in the present case, it is not clear what produced the periodic updrafts since the roll signature was not obvious in the ELDORA data just west of the dryline.

The NRL-P3 flight-level mixing ratio measurements along the north-south oriented tracks are shown in Fig. (3b). Comparing Fig. (3a, b), we can see that the P3 was flying on the dry side of the dryline moisture boundary most of the time (from $\sim 2106: 48$ to $\sim 2112: 30$ ). However, near the southern part of the flight track, the P3 flew through the dryline moisture gradient, which is illustrated by the dramatic change in in situ water vapor mixing ratio over a very short distance, as well as the three moist spots (points $\mathrm{A}^{\prime}, \mathrm{B}^{\prime}$ and $\mathrm{C}^{\prime}$ in Fig. 3b) along the track separated by $\sim 1-2$ minutes $(\sim 8-16 \mathrm{~km})$. An estimation of the moisture gradient near the $2104: 33$ moisture peak (point B' in Fig. 3b) yields a moisture gradient of $\sim 1.7 \mathrm{~g} \mathrm{~kg}^{-1} \mathrm{~km}^{-1}$ in the along-line direction, which is rather large. Also notice that the three peaks in water vapor mixing ratio, which occurred at 2103:50 (point A'), 2104:33 (point B') and 2106:14 (point $\mathrm{C}^{\prime}$ ) in Fig. (3b), correspond well to the three misocyclones A, B, and C in Fig. (3a), with the two moistest spots (point $\mathrm{B}^{\prime}$ and $\mathrm{C}^{\prime}$ ) occurring when the P3 was flying closest to the dryline thinline on its west edge (notice the little bulges of zero dBZe radar reflectivity contour near misocyclones B and C). This seems to suggest that, first, the misocyclones near the dryline thinline modified the thinline structure; and second, the misocyclones located near the moisture gradient distorted the dryline moisture boundary and caused the three moist spots and the dramatic along-line moisture variations. The same conjecture was proposed by Murphey et al. [23] to explain the along-line variability revealed by ELDORA and LEANDRE II observations of the 19 June 2002 dryline during IHOP_2002 (see their figure 18).

How does a misocyclone modify the moisture distribution near a dryline? For an idealized misocyclone with circular motion sitting on a moisture boundary with dry (moist) air on the left (right), it would transport dry (moist) air to the east (west) side on the southern (northern) half of the misocyclone circulation. However, the idealized model should be applied with caution. Normally, a misocyclone is defined by its vertical vorticity value through applying a certain threshold (a threshold of $2 \times 10^{-3} \mathrm{~s}^{-1}$ was used in this paper). Thus, the size and shape of a misocyclone could vary as a result of different vorticity threshold. In reality, a misocyclone's shape, which is largely decided by the vertical vorticity threshold, might not resemble a circle. This makes the application of the above idealized model rather complicated. In essence, it is the exact flow pattern of a misocyclone that intercepts the dryline moisture boundary ultimately determines how the moisture boundary will be distorted. In other words, if the flow associated with a misocyclone near a dryline moisture boundary has a westerly (easterly) component, it would transport dry (moist) air to east (west) side of a dryline. This mechanism of how a misocyclone modifies a dryline moisture boundary seems to be illustrated by the NRL-P3 flight level data shown in Fig. (4). The apparent negative correlations between water vapor mixing ratio and the U-component of flight-level winds near points A', B' and C', which are also indicated in Fig. (3b), seem to suggest that the less westerly or easterly (more westerly) winds correspond to moist (dry) air. At first you would think this is not surprising for a convergence boundary such as a dryline, where you would expect dry (moist) air originated from west (east) side of the boundary, but the negative correlation between water vapor mixing ratio and the U-component of flight level winds along a north-south oriented flight track does suggest a cyclonic 
(a) ELDORA (2102:33 - 2112:35) $0.8 \mathrm{~km} \mathrm{AGL}$

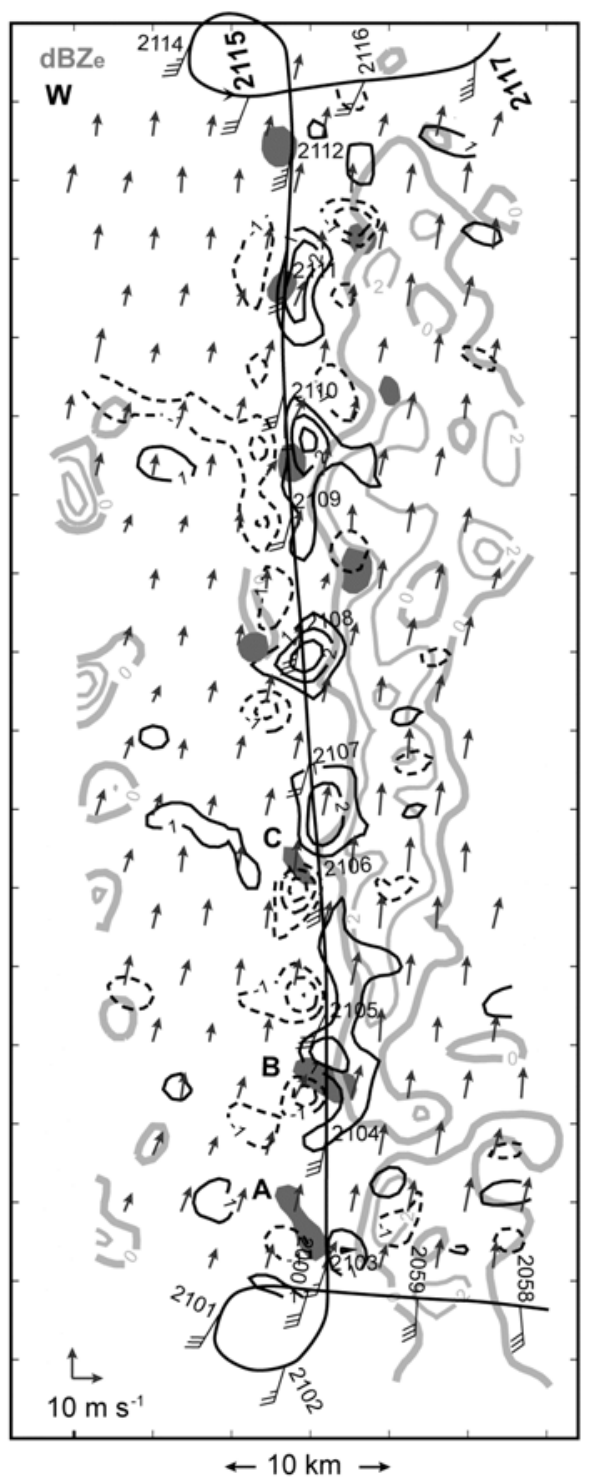

(b) Water Vapor Mixing Ratio

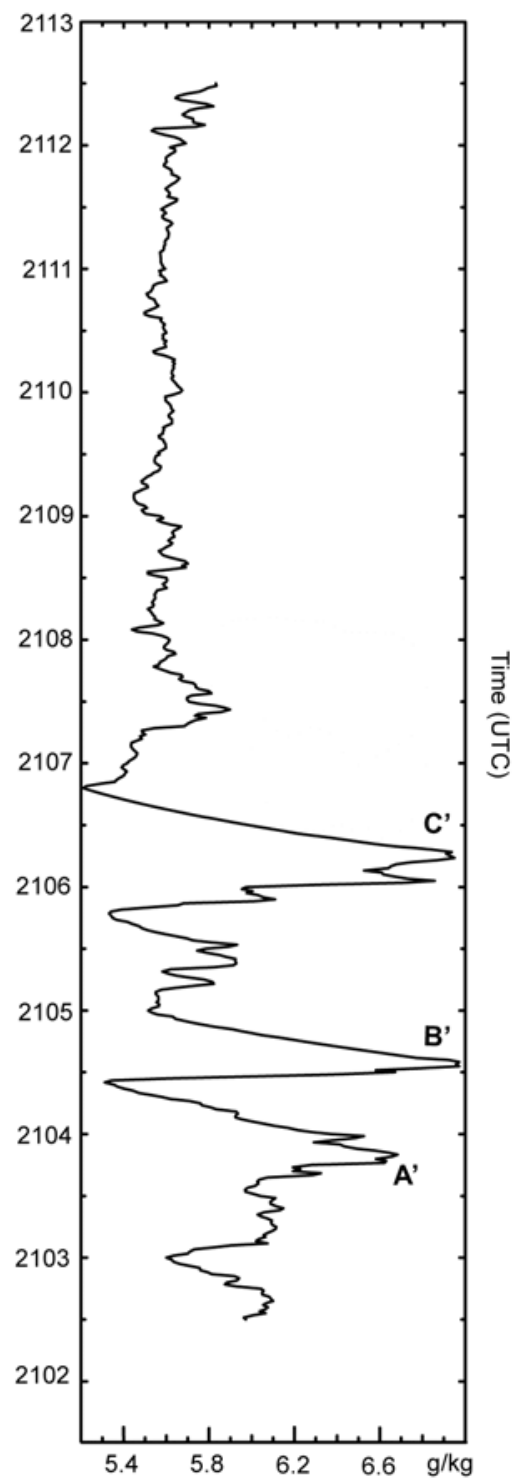

Fig. (3). (a) Dual-Doppler wind synthesis (ground relative), radar reflectivity, vertical velocity and vertical vorticity derived from ELDORA at $0.8 \mathrm{~km}$ (approximate NRL-P3 flight level) AGL during 2102:33 - 2112:35 UTC; (b) Time series of water vapor mixing ratio from NRLP3 flight-level data during the same time period as in (a). Gray contours represent radar reflectivity with contour intervals of $2 \mathrm{dBZ}_{\mathrm{e}}$ (thicker gray lines are the zero $\mathrm{dBZ}_{\mathrm{e}}$ contours). Radar reflectivity contours below zero $\mathrm{dBZ}_{\mathrm{e}}$ are omitted for clarity. Solid (dashed) black lines represent updrafts (downdrafts) with a contour interval of $1 \mathrm{~m} \mathrm{~s}^{-1}$. Vertical vorticity greater than $2 \times 10^{-3} \mathrm{~s}^{-1}$ are shaded gray. NRL-P3 flight tracks (thin black lines) along with time and flight-level winds are also plotted in (a). The dual-Doppler synthesis and LEANDRE II data from the short east-west oriented track between 2115 and 2117 UTC near the northern end of the domain in (a) are shown in Fig. (7a).

wind shift leading to each water vapor mixing ratio maxima. The fact that cyclonic wind shift occurred near a vorticity maximum derived from ELDORA dual-Doppler analysis seems to suggest that the wind shifts measured by NRL-P3 along the north-south oriented flight track near point $A^{\prime}, B^{\prime}$ and ' C' in Fig. (4a) were actually associated with misocyclones A, B, and C in Fig. (3a).

Additional evidence that the three moist spots (A', B', and $C^{\prime}$ ) in Fig. (3b) were caused by the flow pattern of misocyclone $\mathrm{A}, \mathrm{B}$, and $\mathrm{C}$, respectively, was revealed by the orientation of the three misocyclones. Notice the long-axis of misocyclone $\mathrm{A}$ and $\mathrm{C}$ was oriented in the northwestsoutheast direction, with their southern part close to the flight track. This kind of misocyclone flow configuration would produce easterly flow on the east side of the misocyclone and westerly flow near the southern tip of the misocyclone, which subsequently would cause high water vapor content on the east side and low water vapor content near the southern tip of the misocyclone, just as indicated by Fig. (3b). Similarly, since misocyclone $B$ was rather elongated and its long axis was almost oriented in an eastwest direction, a sharp moisture gradient in the north-south direction was produced as shown in Fig. (3b) near point B'.

It is possible that the along-line water vapor mixing ratio variation in Fig. (3b) could be caused by the NRL-P3 flying in/out of thermals with high water vapor content, and 
(a) Mixing Ratio \& U (2103:00--2108:00)

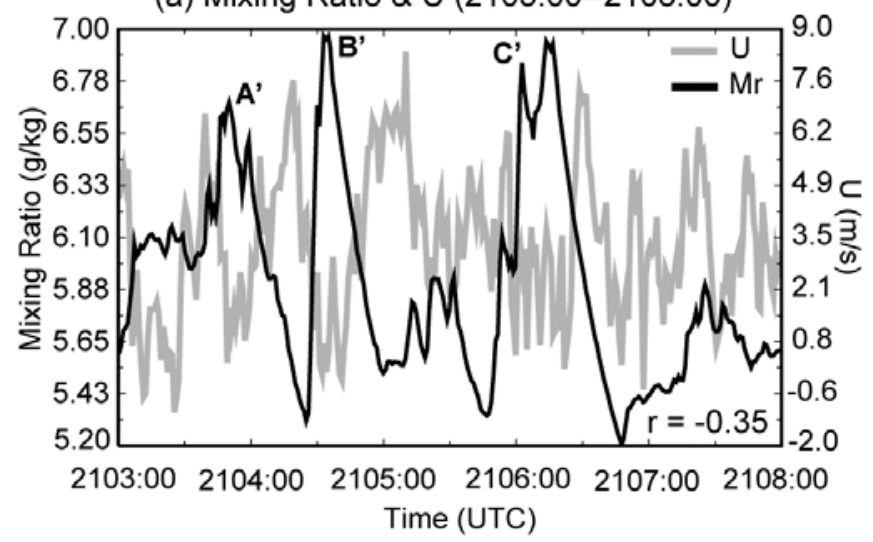

(b) Mixing Ratio \& W (2103:00--2108:00)

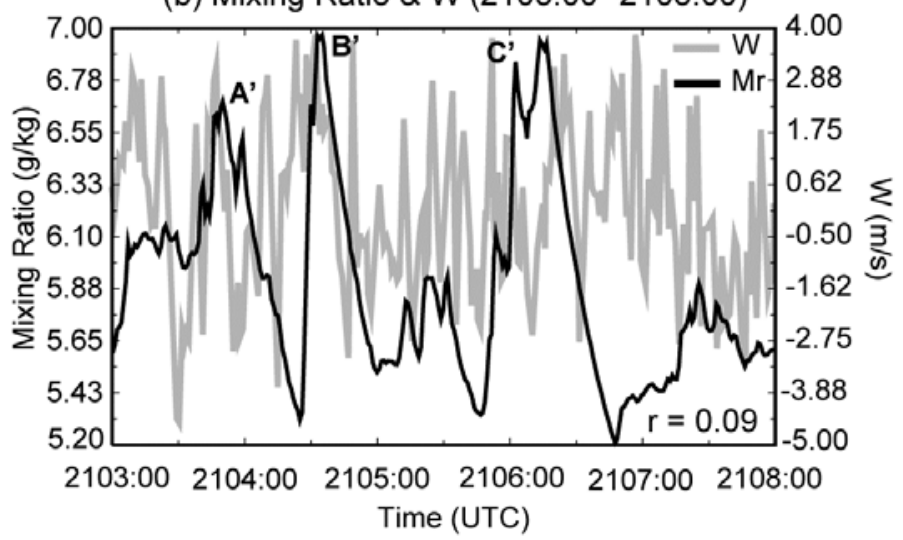

Fig. (4). Time-series of NRL-P3 flight-level data between 2103:00 and 2108:00 UTC. a) Water vapor mixing ratio and the u-component of the flight-level winds $\left(\mathrm{m} \mathrm{s}^{-1}\right)$; b) Water vapor mixing ratio and vertical velocity of the flight-level winds $\left(\mathrm{m} \mathrm{s}^{-1}\right)$. The thin black line represents water vapor mixing ratio $\left(\mathrm{g} \mathrm{kg}^{-1}\right)$ in both panels; the thick gray line represents the u-component of the flight-level winds $\left(\mathrm{m} \mathrm{s}^{-1}\right)$ in panel a) and the vertical velocity of the flight-level winds $\left(\mathrm{m} \mathrm{s}^{-1}\right)$ in panel b), respectively. Points A', B' and C' are the same points as shown in Fig. (3b).

therefore, has nothing to do with misocyclones perturbing the dryline moisture boundary. An examination of correlations between vertical velocity and water vapor mixing ratio along the flight track shown in Fig. (4b) does not support this explanation because there is little correlation $(r=0.09)$ between vertical velocity and water vapor mixing ratio along the $\mathrm{P} 3$ track through the three moist spots $\mathrm{A}, \mathrm{B}$, and $\mathrm{C}$ from 2103:00 to 2108:00.

It should be emphasized that for a misocyclone to create dramatic along-line variability in terms of moisture, the misocyclone must be located near the dryline moisture gradient. Notice that all misocyclones north of misocyclone $\mathrm{C}$ in Fig. (3a) did not produce large moisture variations in the along-line direction, probably because they were mostly located in the dry air side and were too far away from the dryline moisture boundary. Unfortunately this claim could not be confirmed because the exact position of the dryline moisture gradient could not be determined in Fig. (3a) owing to the lack of two-dimensional moisture measurements by LEANDRE II or surface mobile mesonet for this time period.

The horizontal structure of the dryline $\sim 20$ min later is shown in Fig. (5a). Notice the dryline thinline structure has changed dramatically compared to Fig. (3a). The width of the thinline has decreased, and the thinline is less linear and more disorganized, while the updrafts seem to become elongated in the cross-line direction. The P3 flight-level data indicated the P3 was flying mostly on the moist side of the dryline, with several dry spots along the track (see Fig. 5b). The five most prominent dry spots along the P3 track occurred at $\sim 2120: 11$ (point A'), 2121:28 (point B'), 2122:28 (point C'), 2131:24 (point D') and 2132:38 (point $\left.E^{\prime}\right)$. The low value of water vapor mixing ratio at point A' is a result of NRL-P3 flying into the dry side of the dryline moisture boundary based on P3 flight-level data before 2020:00 (not shown). In contrast, the other two driest spots (point C' and E') correspond to the two local minima in radar reflectivity field with the thinlines occurring on both sides of the P3 track. Similar to Fig. (3b), the strong moisture gradient in the along-line direction (e.g., $\sim 1.7 \mathrm{~g} \mathrm{~kg}^{-}$
${ }^{1} \mathrm{~km}^{-1}$ near point E') was derived from Fig. (5b). The strong moisture gradient in the along-line direction is produced by a moderate moisture difference over a very short distance (e.g., $1.84 \mathrm{~g} \mathrm{~kg}^{-1}$ over a distance of $\sim 1.08 \mathrm{~km}$ near point $\mathrm{E}^{\prime}$ in Fig. 5b). Notice the dry spots at B', C', D' and E' in Fig. (5b) correspond well with misocyclones B, C, D and E in Fig. (5a). The observation that misocyclones $\mathrm{D}$ and $\mathrm{E}$ were too far away from the P3 track to cause the observed moisture change along the track is addressed by including the $1 \times 10^{-3} \mathrm{~s}^{-}$ ${ }^{1}$ vertical vorticity contour just for misocyclones $\mathrm{D}$ and $\mathrm{E}$ in Fig. (5a). Apparently misocyclones $\mathrm{D}$ and $\mathrm{E}$ were much closer to the P3 track indicated by the $1 \times 10^{-3} \mathrm{~s}^{-1}$ contour instead of the shaded area, which represents vertical vorticity greater than $2 \times 10^{-3} \mathrm{~s}^{-1}$. Fig. (5), as well as Fig. (3), clearly suggest that the large moisture gradient in the along-line direction near the dryline thinline is caused by misocyclones near the dryline moisture boundary. Notice misocyclones B, $\mathrm{C}$, and D's long-axis are all oriented in northeast-southwest direction, which suggests the air flow on the southeast side of the misocyclone would have a westerly component, and thus produce a dry spot along the flight track if this westerly flow happened to be sampled by NRL-P3. The flow pattern associated with misocyclone $\mathrm{E}$ in Fig. (5a) could also produce the dry spot E' in Fig. (5b).

Similar to Fig. (4), P3 flight-level water vapor mixing ratio, U-component of flight-level winds, vertical velocity as well as their correlations corresponding to Fig. (5) are shown in Fig. (6). Generally, the water vapor mixing ratio and the U-component of the flight level winds showed a higher, negative correlation (-0.31 and -0.64 in Fig. 6a, c) compared with the correlation between water vapor mixing ratio and vertical velocity, which showed a lower, positive correlation (0.13 and 0.49 in Fig. $6 \mathbf{b}, \mathbf{d}$ ), respectively. The unusual high correlation between water vapor mixing ratio and vertical velocity in Fig. (6d) was mostly caused by a large, dry downdraft, and, therefore, it cannot be used to support the thermal conjecture mentioned earlier. Four dry spots (point B', C', D', and E') are clearly associated with peaks of westerly winds, indicating that strong westerly winds were transporting dry air from west to east across the dryline. Also notice in Fig. (6) that the moist spots are generally associated 
(a) ELDORA (2120:04 - 2134:04) $0.8 \mathrm{~km} \mathrm{AGL}$

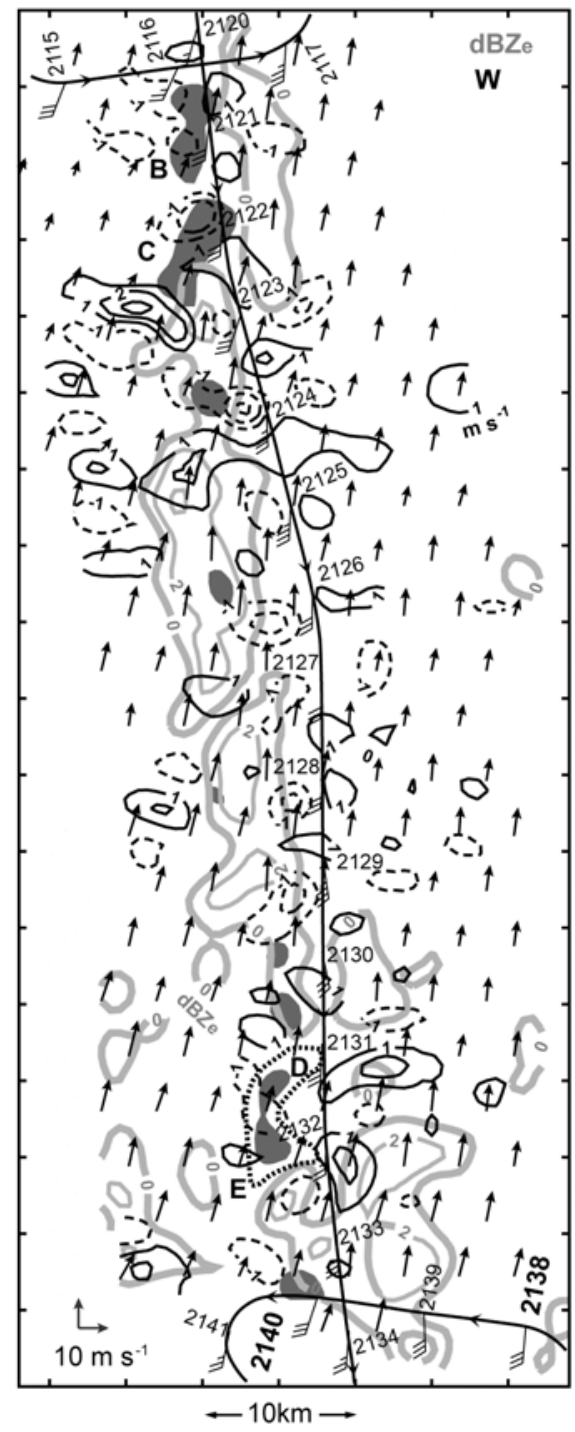

(b) Water Vapor Mixing Ratio

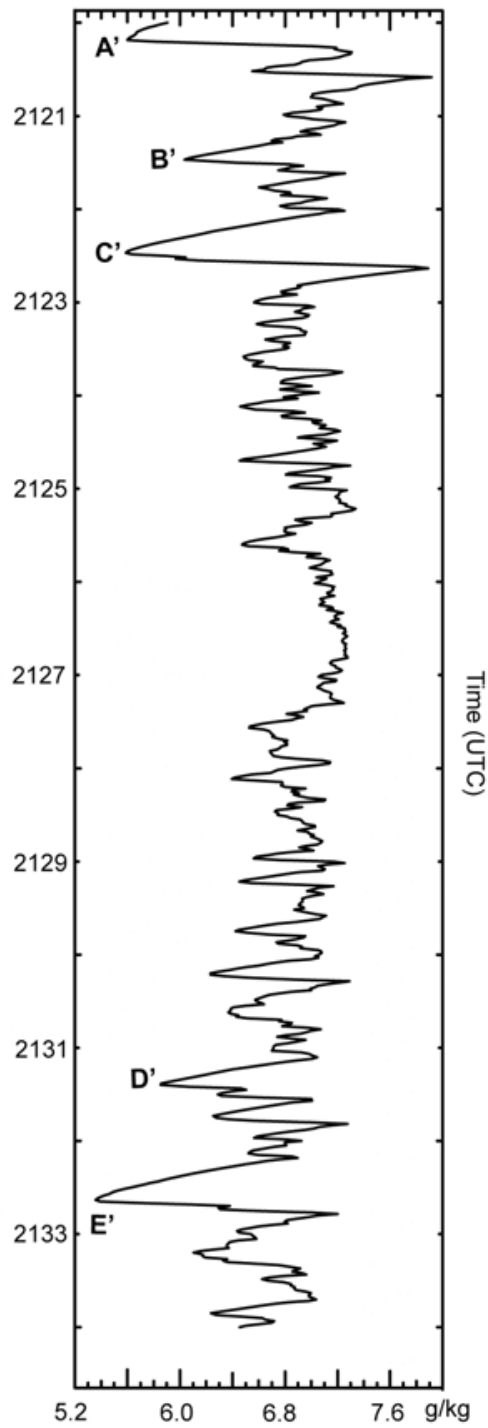

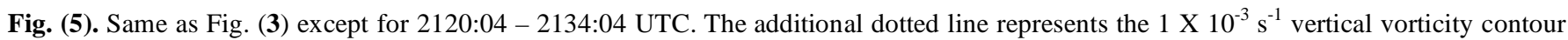
associated with misocyclones D and E only. The dual-Doppler synthesis and LEANDRE II data from the short east-west oriented track between 2138 and 2140 UTC near the southern end of the domain in (a) are shown in Fig. (7b).

with easterly winds, and, leading to each of the dry spots, winds were shifting from easterly or less westerly to more westerly along the north-south oriented flight track. Once again, the cyclonic wind shift from flight level winds in addition to nearby local vertical vorticity maxima derived from ELDORA dual-Doppler analysis suggests the existence of misocyclones near the dryline and their effects on distortion of dryline moisture boundary.

It should be pointed out that the strong along-the-track moisture variations shown in Figs. $(\mathbf{3 b}, \mathbf{5 b})$ could also possibly be explained by assuming that the NRL P3 happened to fly within the dryline mixing zone oriented in the north-south direction and therefore could easily drift across the dryline moisture boundary with relatively small east-west displacement; however, evidence will be presented in the next section to show that it is highly unlikely that the wet and dry spots showed in Figs. $(\mathbf{3 b}, \mathbf{5 b})$ were caused by this mechanism.

\subsection{Horizontal Cross-Line Structure}

The detailed horizontal structure of the 9 June 2002 dryline in the cross-line direction as revealed by ELDORA and LEANDRE II are shown in Fig. (7). A careful examination of relations between radar reflectivity and updrafts in Fig. (7) suggests that local maxima of radar reflectivity tend to be closely associated with updrafts, as shown by previous studies (e.g., $[6,11,15,36])$ however, they are not exactly co-located. The updrafts tend to be shifted slightly to the west/southwest of the local radar reflectivity maximum. This might be a result of the tilt of dryline thinline in the vertical as described by Miao and Geerts [17], and it also could explain why the correlation 
(a) Mixing Ratio \& U (2121:00--2124:00)
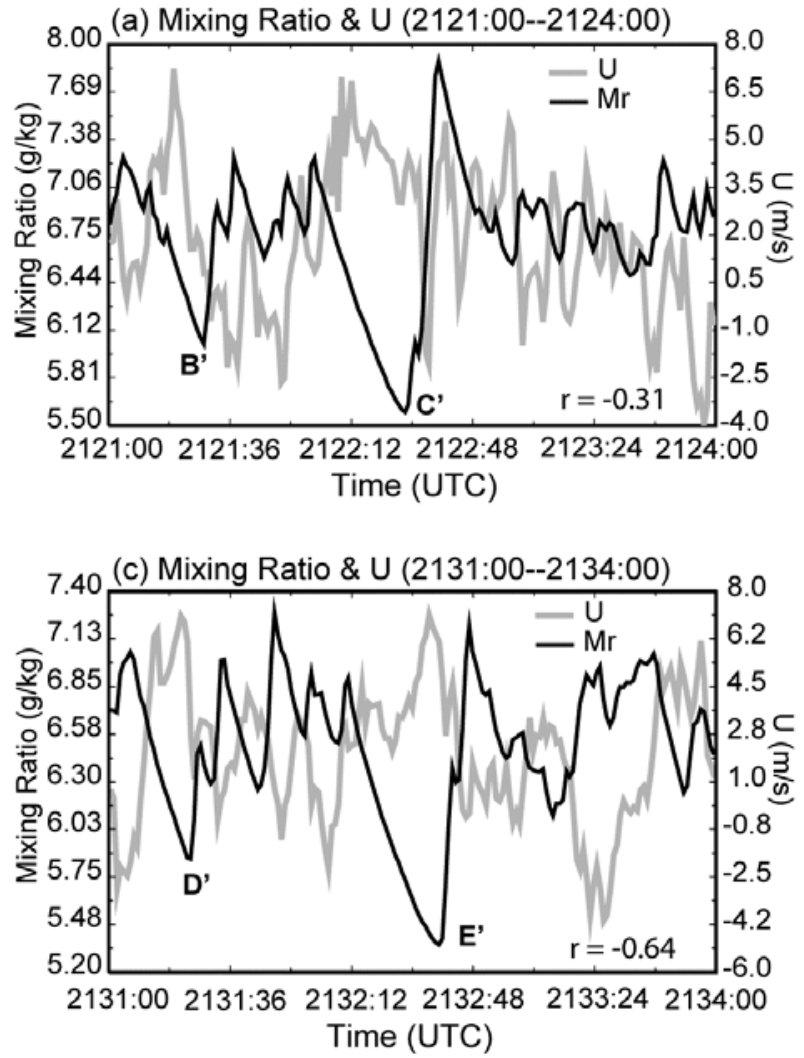

(b) Mixing Ratio \& W (2121:00--2124:00)

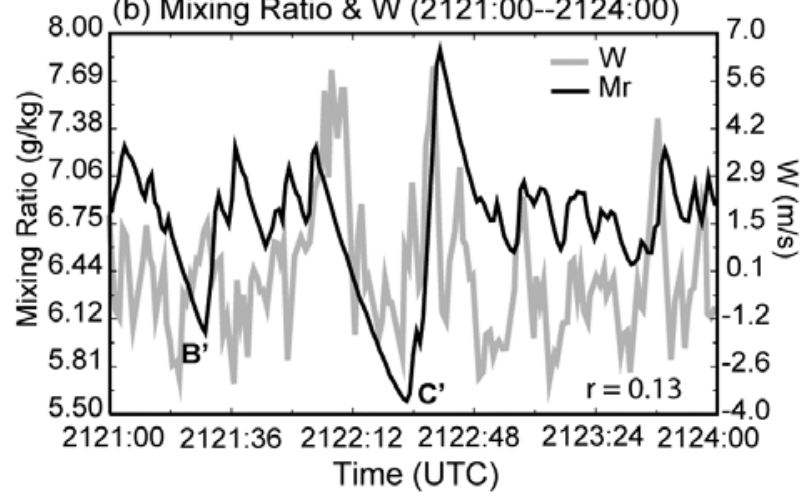

(d) Mixing Ratio \& W (2131:00--2134:00)

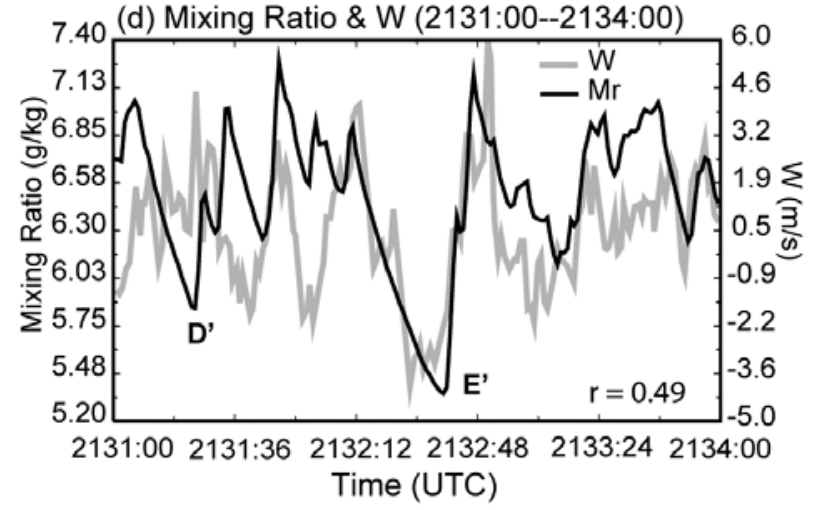

Fig. (6). Same as Fig. (4) except for 2121:00-2124:00 UTC (panels a and b) and 2131:00-2134:00 UTC (panels c and d), respectively. Points B', C', D' and E' are the same points as shown in Fig. (5b).

between radar reflectivity and vertical velocity was almost nonexistent [17]. Also notice from Fig. (7) that the strongest downdrafts are generally associated with local radar reflectivity minimum. The relationship between radar reflectivity and vertical air motion near clear-air boundaries is easy to understand, considering the radar clear-air returns are most likely produced by bugs in the atmospheric boundary layer $[36,37]$. Since the source of the clear-air returns is near the surface, it is expected that 1) updrafts (downdrafts) are associated with stronger (weaker) radar echoes, respectively; and 2) stronger echoes should correspond to stronger updrafts $[6,36]$. A careful examination of Fig. (7) corroborates the first conclusion above, but exceptions to the second conclusion are apparent in Fig. (7a). The strongest updraft in Fig. (7a), which reached $\sim 3 \mathrm{~m} \mathrm{~s}^{-1}$ north of the $\mathrm{P} 3$ track, occurred in an area with radar reflectivity between -3 and $0 \mathrm{dBZ}_{\mathrm{e}}$, that is smaller than the radar reflectivity values south of the flight track. On the other hand, the two strongest updrafts $\left(\sim 3 \mathrm{~m} \mathrm{~s}^{-1}\right)$ in Fig. (7b), which occurred north of the flight track, did correspond to two areas with the largest radar reflectivity ( 3 and $4 \mathrm{dBZ}_{\mathrm{e}}$, respectively).

The width of the dryline thinline could vary dramatically in different parts of the dryline. While Fig. (7a) suggests a dryline thinline width of $\sim 4 \mathrm{~km}$, Fig. (7b) shows a segment of the dryline thinline as wide as $\sim 14 \mathrm{~km}$. The wider radar reflectivity pattern does correspond to elongated updrafts in the cross-line direction shown south of the flight track in Fig. (7b); however, north of the track, updrafts are much narrower than the width of the dryline thinline.
The LEANDRE II water vapor mixing ratio measurements superimposed on the ELDORA dual-Doppler synthesis in Fig. (7) showed the moisture boundary associated with the dryline in the cross-line direction and two-dimensional moisture variations on both side of the dryline. Past studies of dryline based on aircraft in situ data [6] found that the dryline updrafts tend to be collocated with the dryline moisture gradient, which is corroborated by the water vapor DIAL measurements and vertical velocity fields derived from ELDORA shown in Fig. (7).

The water vapor mixing ratio along the P3 flight track in the cross-line direction corresponding to Fig. (7) is shown in Fig. (8). The close resemblance of water vapor mixing ratio magnitude and change across the dryline as detected by P3 in situ measurements and LEANDRE II supports the accuracy of the moisture data from LEANDRE II, consistent with the finding by Murphey et al. [23] using the same technique.

The moisture differences across the 9 June dryline $(\sim 1.1$ $1.8 \mathrm{~g} \mathrm{~kg}^{-1}$ ) were near the low end of dryline spectrum [17], however, its moisture gradients can vary from $\sim 0.6--\sim 1.0 \mathrm{~g}$ $\mathrm{kg}^{-1} \mathrm{~km}^{-1}$ near the northern end of the IOR (Fig. 8a) and $\sim 0.2$ -- $\sim 0.5 \mathrm{~g} \mathrm{~kg}^{-1} \mathrm{~km}^{-1}$ near the southern end of the IOR (Fig. $\mathbf{8 b}$ ), depending on how the width of dryline mixing zone is chosen. For example, the upper limit of the moisture gradients near the northern end of the IOR (i.e., $\sim 1.0 \mathrm{~g} \mathrm{~kg}^{-1}$ $\mathrm{km}^{-1}$ ) was derived from the steepest increase in water vapor mixing ratio from $2116: 05$ to $2116: 15$, a 10 second period in Fig. (8a) which corresponded to $\sim 1.2 \mathrm{~g} \mathrm{~kg}^{-1}$ in moisture difference and $\sim 1.2 \mathrm{~km}$ in cross-line distance. On the other hand, the lower limit of the moisture gradients near the 


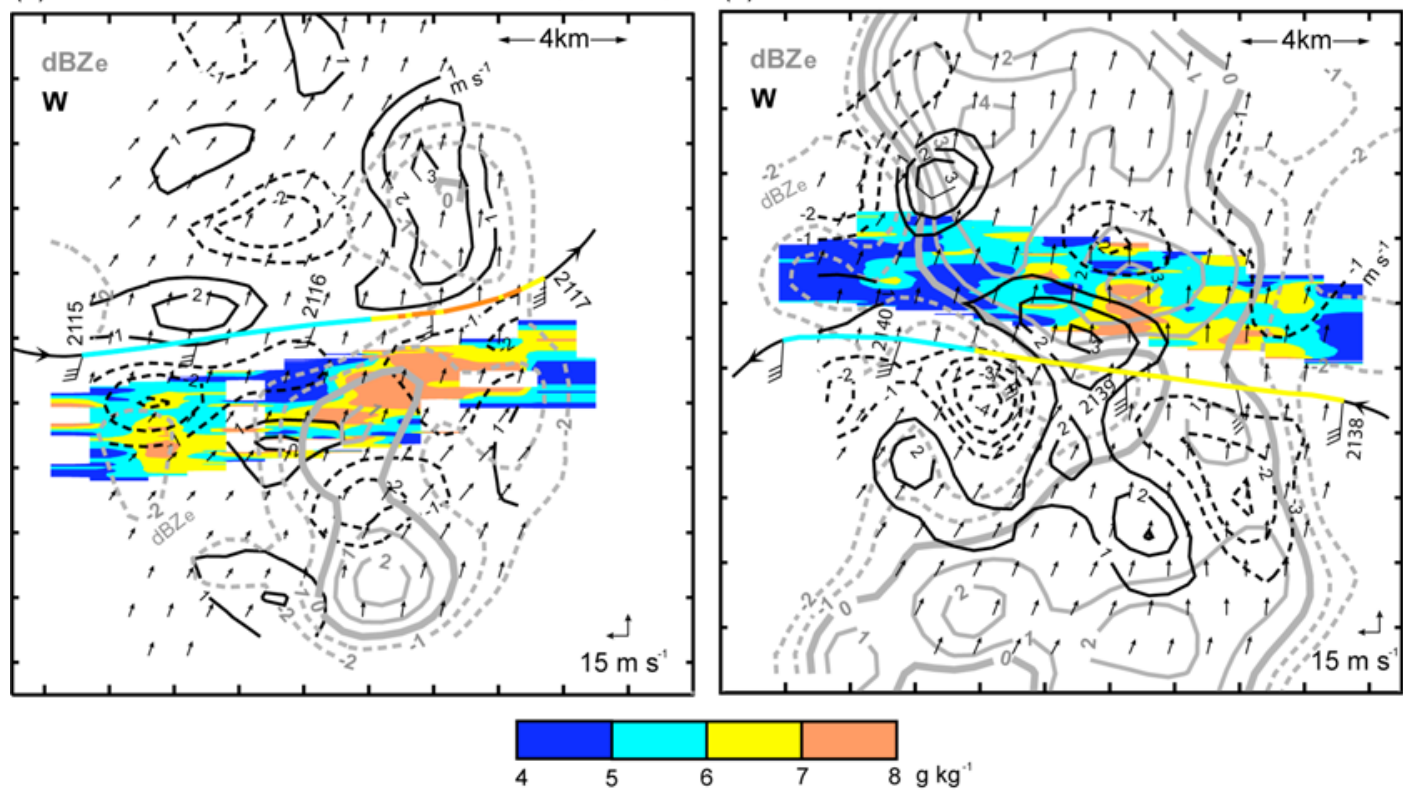

Fig. (7). Water vapor mixing ratio from LEANDRE II superimposed on Dual-Doppler wind synthesis (ground relative), radar reflectivity, and vertical velocity derived from ELDORA at 0.8 km AGL; (a) 2115:03 - 2116:51 UTC, and (b) 2138:03 - 2140:25 UTC. Gray (dashed gray) contours represent positive (negative) radar reflectivity with a contour interval of $1 \mathrm{dBZ}_{\mathrm{e}}$. Radar reflectivity contours below $-2 \mathrm{dBZ}$ are omitted for clarity. Solid (dashed) black lines represent updrafts (downdrafts) with a contour interval of $1 \mathrm{~m} \mathrm{~s}^{-1}$. NRL-P3 flight tracks (thick black lines) are color-coded with water vapor mixing ratio along the track using the same color table as that of LEANDRE II data. Time and flight-level wind barbs are also plotted along the P3 track in both (a) and (b).

northern end of the IOR (i.e., $\sim 0.6 \mathrm{~g} \mathrm{~kg}^{-1} \mathrm{~km}^{-1}$ ) was derived from a more typical dryline mixing zone width of $\sim 2.8 \mathrm{~km}$ from 2116:05 to 2116:28. Since the dryline mixing zone has a typical width of $1-10 \mathrm{~km}$ based on past studies (e.g., [17, $38]$ ), the 9 June dryline seems to fall on the lower end of dryline mixing zone spectrum. This observation, in addition to the broad width of the thinline of the 9 June dryline, seems to suggest that there is no relation between the width of a dryline thinline and the width of its mixing zone.

The virtual potential temperature differences are $\sim 0.6$-$\sim 1.0 \mathrm{~K}$ across the dryline, which is comparable to past dryline studies (e.g., [17]). Pockets of updrafts as strong as 5-6 $\mathrm{m} \mathrm{s}^{-1}$ are noted in Fig. (8). Also confirmed by Fig. (8) is a previous finding (e.g., [3]) that the moisture gradient is closely associated with updrafts. However, not all updrafts are associated with a moisture gradient, as shown by the largest updraft which occurred at 2115:08 (Fig. 8a).

It is noteworthy to point out that, based on this case study, at some segments of a dryline, the along-line moisture gradient could exceed the cross-line moisture gradient, which seems counter-intuitive at first. We hypothesized in the previous section that the large moisture gradient produced by dry (wet) spots along the $\mathrm{P} 3$ track is caused by the fact that the P3 flight-level data was able to resolve misocyclones sitting near the dryline moisture boundary, which distorted the dryline moisture boundary and created a large moisture gradient in the along-line (quasi-north-south) direction. The other possible explanation of the large alongtrack moisture variations shown in Figs. $(\mathbf{3 b}, \mathbf{5 b})$ is that the P3 could just happen to be flying within the dryline moisture boundary, and, therefore, could simply drift across the (a) 2115:00--2116:30

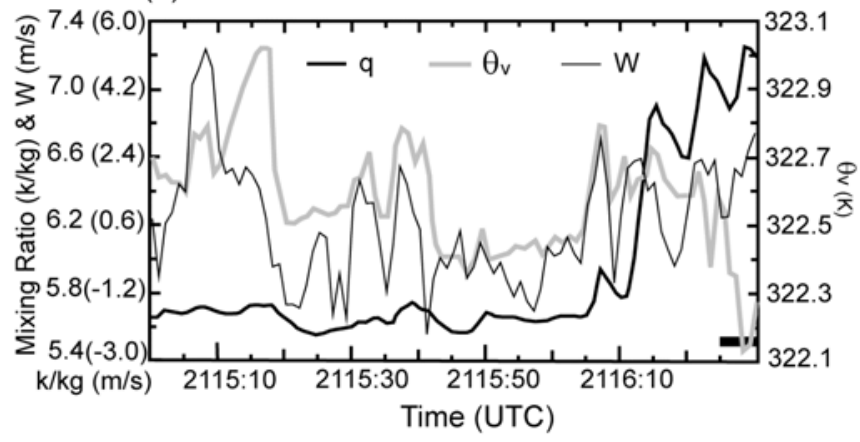

(b) 2138:00--2140:30

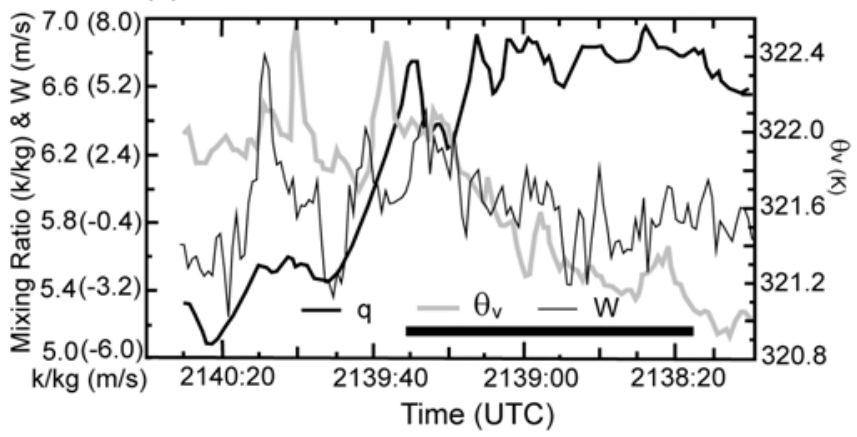

Fig. (8). Time series of NRL-P3 flight-level data as it flown across the dryline during approximately same time period as in Fig. (7a, b). Water vapor mixing ratio (q, thick black lines), virtual potential temperature $\left(\theta_{v}\right.$, gray lines) and vertical velocity ( $w$, thin black lines) are plotted. The black bars near the bottom of each panel indicate the time periods when ELDORA radar reflectivity along the P3 track was greater than $-2 \mathrm{dBZ}_{\mathrm{e}}$. (a) 2115:00 - 2116:30, and (b) 2138:00 - 2140:30 UTC. 
dryline moisture boundary when it was flying predominantly in the north/south direction. In this scenario no misocyclones are needed to produce a distorted dryline moisture boundary; in other words, a more or less locally linear north-south oriented dryline moisture boundary could also produce the dry (wet) spots in Figs. (3b, 5b), depending on where the aircraft was flying. This scenario certainly could happen, but we are arguing that it is not the cause of large along-line moisture variations observed in the 9 June dryline case for the following reasons: 1) as we showed in the previous section, each dry (wet) spot showed in Figs. $(\mathbf{3 b}, \mathbf{5 b})$ in the along-line direction from P3 flight-level data was associated with a misocyclone nearby which was revealed by ELDORA dual-Doppler analysis; 2) if we assumed the dryline moisture boundary was locally linear, and it was oriented in the northsouth direction, each dry (wet) spot in Figs. $(\mathbf{3 b}, \mathbf{5 b})$ would have required the P3 to fly across the dryline moisture gradient zone and come back again in a matter of less than several tens of seconds. The dryline mixing zone width could vary dramatically, as Fig. (8) suggested. The narrowest width of the dryline cross-line moisture gradient zone derived from Fig. (8a) is $\sim 1.2 \mathrm{~km}$, with more typical values of $\sim 2-3 \mathrm{~km}$ derived from Fig. (8b). This seems to suggest that the P3 had to fly at least over $\sim 1.2 \mathrm{~km}$ in the east-west direction to cross a quasi-north-south dryline moisture boundary. A careful examination of the P3 track revealed that, first, the aircraft never traveled more than $\sim 355 \mathrm{~m}$ in the east-west direction near all the large moisture gradient spots in Figs. $(\mathbf{3}, \mathbf{5})$, and, second, there were no apparent turns by P3 near the dry (wet) spots in Figs. $(\mathbf{3 b}, \mathbf{5 b})$. Therefore, it seems reasonable to suggest that in this case, the large alongline (i.e., along-track in Figs. 3, 5) moisture variation is indeed produced by the P3 flying across a distorted dryline moisture boundary caused by misocyclones near the dryline moisture gradient.

The two-dimensional LEANDRE II data in Fig. (7) do suggest that small-scale variations in the moisture field on the order of $\sim 1 \mathrm{~g} \mathrm{~kg}^{-1}$ on both sides of the dryline are rather common. In other words, moisture fields are not homogeneous on either side of the dryline. This could result from LEANDRE II sampling moist plumes of various heights near the flight level. Since results from Crook [39] suggested that moisture change on the order of $\sim 1 \mathrm{~g} \mathrm{~kg}^{-1}$ could influence whether or not convection will initiate, and Weckwerth [40] demonstrated that small-scale moisture variability, which could not be resolved by the operational observational networks, has tremendous impact on storm initiation, the observations showed in Fig. (7) certainly have important implications in terms of forecasting new storms. It is further speculated that small moisture variations, in addition to locations and strength of updrafts, each having horizontal scales of several kilometers, will most likely determine where and when storms are going to form. Since the current operational observational networks are not able to meet the above requirements, it is not surprising that convection initiation forecasts both by numerical models and nowcasting techniques in the warm season remain a great challenge.

\subsection{Vertical Structure and Convection Initiation}

The averaged vertical cross-section of radar reflectivity, vertical velocity and vertical vorticity corresponding to Figs. $(\mathbf{3}, \mathbf{5})$ along the north-south direction are shown in Figs. (9, 10), respectively. The averaged updrafts of the 9 June dryline were weak, showed a slight tilt to the east, and were generally associated with a radar reflectivity thinline signature. The tilt of the dryline updraft was also demonstrated in other averaged dryline vertical crosssections (e.g., $[15,23])$ and observed by Wyoming cloud radar [17]. The averaged winds in the vertical cross-section showed a typical wave-like pattern, which was consistent with previous studies (e.g., [7]). Also, a weak, closed secondary circulation associated with the dryline at the low level is noted in Fig. (9).

The large scale water vapor mixing ratio distribution observed by LASE in a east-west vertical cross section spanning over $\sim 700 \mathrm{~km}$ in horizontal and $5 \mathrm{~km}$ in vertical is shown in Fig. (11). The dryline position is hard to pinpoint based on LASE data alone owing to the weak water vapor mixing ratio difference across the 9 June dryline and the coarse horizontal resolution of LASE, however, a general increase of moisture from west to east is evident. As a matter of fact, the moisture kept increasing eastward until $\sim 200 \mathrm{~km}$ east of the dryline, where it reached a maximum of $\sim 16 \mathrm{~g} \mathrm{~kg}$ ${ }^{1}$. The water vapor in the atmospheric boundary layer is wellmixed on both sides of the dryline, as indicated by the almost vertical water vapor mixing ratio color contours in Fig. (11). Notice the water vapor content near the dryline is rather low $\left(\sim 5-7 \mathrm{~g} \mathrm{~kg}^{-1}\right)$, which could be one of the reasons that the 9 June dryline did not initiate any storms inside the IOR.

The vertical structure of the 9 June dryline as depicted by the Learjet dropsonde data is shown in Fig. (12). Also plotted in Fig. (12) are some atmospheric stability parameters important to convection initiation, such as lifted index (LI), lifted condensation level (LCL), and level of free convection (LFC), each calculated using the dropsonde data. Other atmospheric instability parameters such as CSI (conditional symmetric instability) and MPV (moist potential vorticity) [41, 42] were also considered but could not be calculated owing to the lack of three dimensional moisture data. As indicated in Fig. (12), the LCL is higher on the west side of the dryline as expected, and there are no LFC for all soundings west of the dryline. There is marginal atmospheric instability $\sim 40-80 \mathrm{~km}$ east of the dryline, as indicated by the appearance of LFC at $\sim 650 \mathrm{mb}$ and a LI value of -1.3 .

The water vapor mixing ratio near the dryline is between $\sim 5$ and $\sim 6.5 \mathrm{~g} \mathrm{~kg}^{-1}$ based on the dropsonde data, which is consistent with LASE, LEANDRE II, and NRL-P3 flight level data. The winds are southerly east of the dryline (dropsonde D7) and southwesterly west of the dryline (dropsonde D6) near the surface, suggesting a weak surface convergence between dropsondes D6 and D7. The water vapor is well-mixed near the dryline, with the atmospheric boundary layer depth greater on the west side of the dryline after considering the terrain effect.

Two soundings, one on the moist side released by National Severe Storms Laboratory's (NSSL) mobile crew and the other in the dry air by NCAR mobile sounding unit, are shown in Fig. (13). A temperature inversion at $\sim 500 \mathrm{mb}$ at the moist side of the dryline was noted, which created a CIN (Convective INhibition) value of $\sim 41 \mathrm{~J} \mathrm{~kg}^{-1}$. Considering a capping inversion (a CIN of $\sim 41$ ), a low moisture content (water vapor mixing 

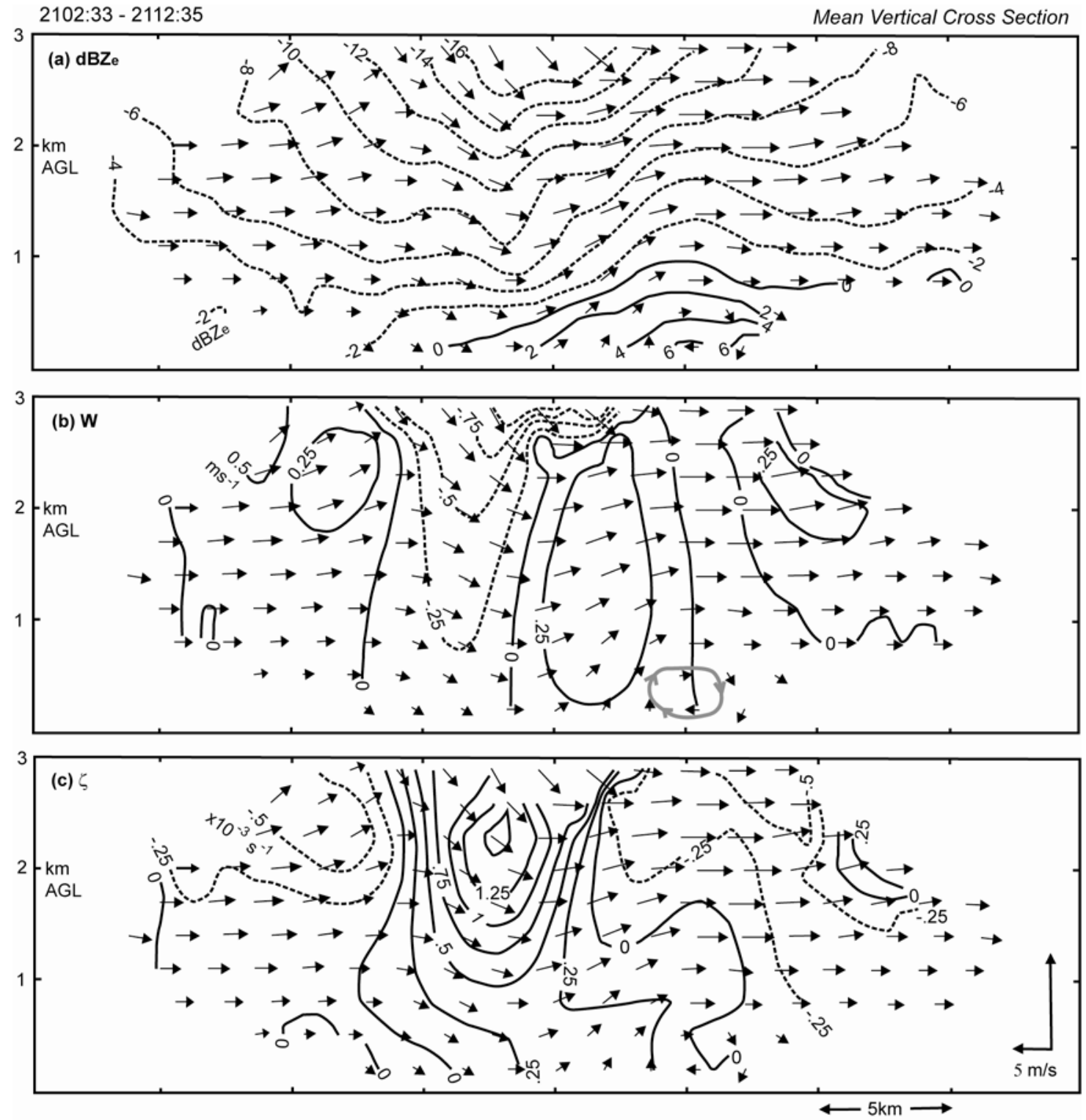

Fig. (9). Averaged dryline vertical cross-section along the dryline derived from ELDORA corresponding to Fig. (3). a) Radar reflectivity $\left(\mathrm{dBZ}_{\mathrm{e}}\right)$ with contour interval of $\left.2 \mathrm{dBZ}_{\mathrm{e}} ; \mathbf{b}\right)$ Vertical velocity $\left(\mathrm{m} \mathrm{s}^{-1}\right)$ with contour interval of $0.25 \mathrm{~m} \mathrm{~s}^{-1}$; and c) Vertical vorticity $\left(\mathrm{x} 10^{-3} \mathrm{~s}^{-1}\right)$ with contour interval of $0.25 \times 10^{-3} \mathrm{~s}^{-1}$. Positive (negative) values are represented by solid (dashed) lines and ground relative winds are superimposed on all panels. The gray circle in panel $\mathrm{b}$ indicates the closed secondary circulation associated with the dryline.

ratio of $\sim 6 \mathrm{~g} \mathrm{~kg}^{-1}$ and a relative humidity of $\sim 20 \%$ ), as well as a relatively weak upward forcing (maximum vertical velocity $\sim 3$ $\mathrm{m} \mathrm{s}^{-1}$ based on ELDORA), it is not surprising that no storms were initiated near the dryline inside the IOR. As a matter of fact, the 9 June dryline was one of the few cases where a correct null forecast of convection initiation was issued by the operation center during the IHOP_2002 field campaign (see IHOP_2002 field catalog at http://catalog.eol.ucar.edu/ihop/catalog/index. html).

\section{SUMMARY AND DISCUSSION}

A detailed observational study of the 9 June dryline during IHOP_2002 is presented. The analyses of the 9 June dryline are special in the following aspects compared with previous dryline studies: 1) this dryline was probably one of the weakest drylines observed during IHOP_2002 in terms of water vapor mixing ratio difference across the dryline $(\sim 1.1$ -
$1.8 \mathrm{~g} \mathrm{~kg}^{-1}$ based on NRL-P3 flight level data), updrafts near the dryline convergence boundary $\left(\leq \sim 3 \mathrm{~m} \mathrm{~s}^{-1}\right.$ based on ELDORA dual-Doppler synthesis), and vertical vorticity associated with the misocyclones near the dryline $\left(\leq \sim 3 \mathrm{~s}^{-1}\right.$, also based on ELDORA data); 2) simultaneous observations of a dryline by a Doppler radar (i.e., ELDORA) and two water vapor DIALs (i.e., LEANDRE II and LASE) are rare; 3 ) case studies of drylines that did not initiate storms are relatively rare in the literature.

Large along- and cross-line variability in terms of vertical velocity (ranging from $\sim-4$ to $\sim 3 \mathrm{~m} \mathrm{~s}^{-1}$ ), moisture content $\left(\sim 1 \mathrm{~g} \mathrm{~kg}^{-1}\right)$ and dryline thinline structure are noted. Updrafts (downdrafts) are found to be closely associated with local maxima (minima) of radar reflectivity, but the two are not co-located. The updrafts also tend to be located near the moisture gradient across the dryline, similar to previous 

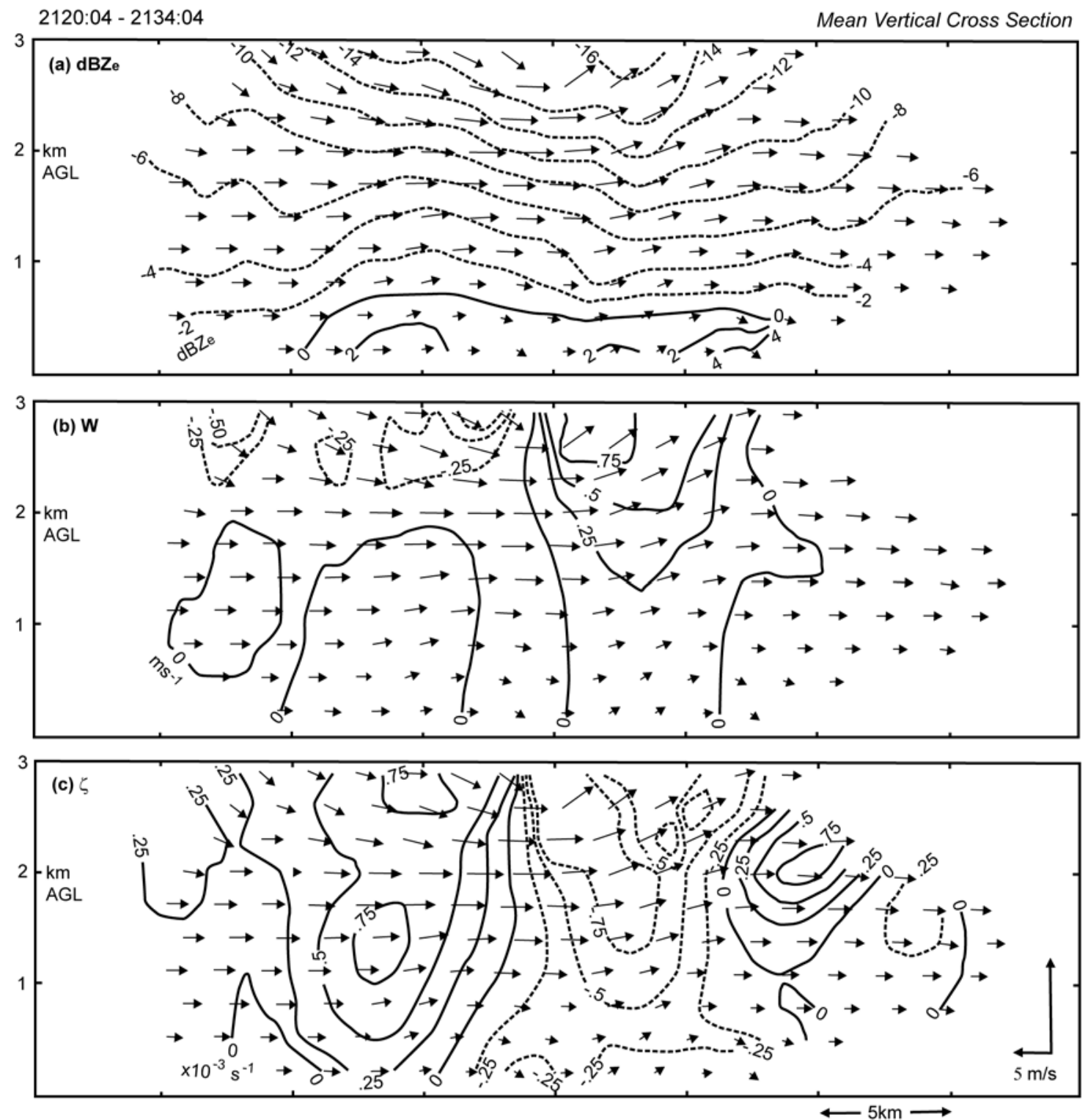

Fig. (10). Same as Fig. (9) except for the time period corresponding to Fig. (5).

findings (e.g., [6]). One subtle difference between this dryline study and some other previous studies of clear-air boundaries (e.g., [36]) is the relation between stronger updrafts and stronger radar reflectivity. In the current study, the strongest updrafts do not necessarily correspond to the strongest radar reflectivity, even in the same dryline. Similar conclusions have also been reached by Wakimoto and Murphey [14].

Although the dryline thinline width, which is defined as the width of the region enclosed by the zero $\mathrm{dBZ}_{\mathrm{e}}$ radar reflectivity contours, was generally wider for the 9 June 2002 dryline compared with other drylines, the moisture gradient associated with the 9 June dryline was large (ranging from $\sim 0.2$ to $\sim 1.7 \mathrm{~g} \mathrm{~kg}^{-1} \mathrm{~km}^{-1}$ in both along- and cross-line directions). More importantly, it was found that the moisture gradient in the along-line direction at certain segments of the 9 June 2010 dryline could exceed that in the cross-line direction, probably as a result of the P3 flight-level moisture data being able to resolve small scale sharp moisture change produced by misocyclones sitting near the dryline moisture gradient.

The two-dimensional horizontal water vapor mixing ratio field derived from LEANDRE II clearly identifies the dryline moisture boundary as well as the moisture variations on both sides of the dryline. It is important to emphasize that moisture variations on the order of $\sim 1 \mathrm{~g} \mathrm{~kg}^{-1}$ are rather common on both sides of the dryline on horizontal scales of several kilometers, which has important implications regarding our ability to forecast convection initiation.

Vertical structure of the 9 June dryline was depicted by ELDORA, LASE and Learjet dropsonde data. A secondary circulation in the averaged vertical cross-section associated with the dryline was noted. Because of a capping inversion and low moisture content near the dryline, the atmospheric instability were marginal for new storm initiation (e.g., LI = -1.3 at best). On top of the not-so-favorable atmospheric instability conditions, the upward forcing near the dryline was also weak (maximum updrafts $\sim 3 \mathrm{~m} \mathrm{~s}^{-1}$ based on 


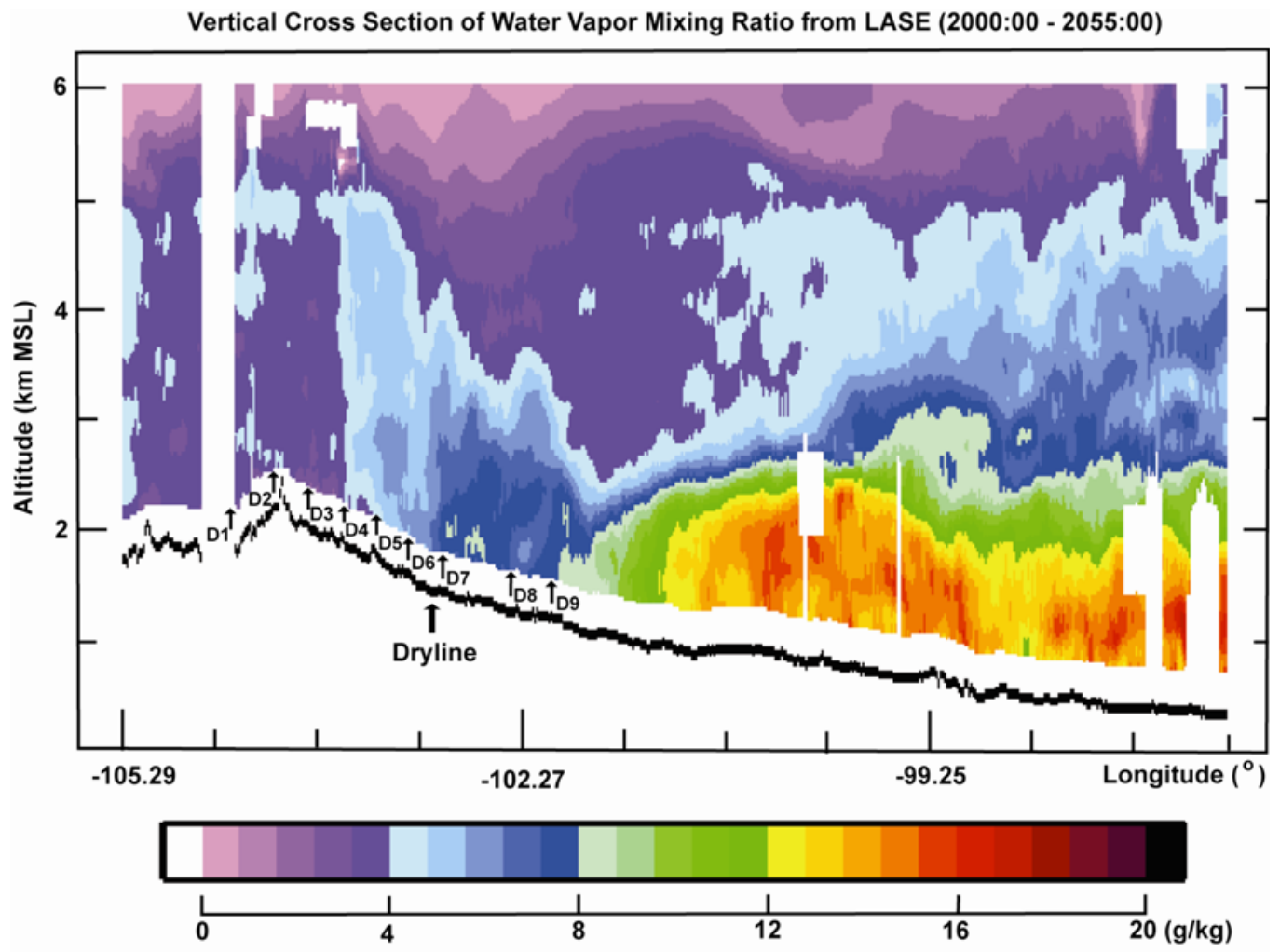

Fig. (11). Vertical cross-section of water vapor mixing ratio $\left(\mathrm{g} \mathrm{kg}^{-1}\right)$ obtained by LASE during 2000:00-2055:00 (adapted from IHOP_2002 field catalog). The approximate positions of 9 dropsondes are also plotted (D1-D9). The NASA DC-8 flight track for this vertical crosssection is shown in Fig. (2).

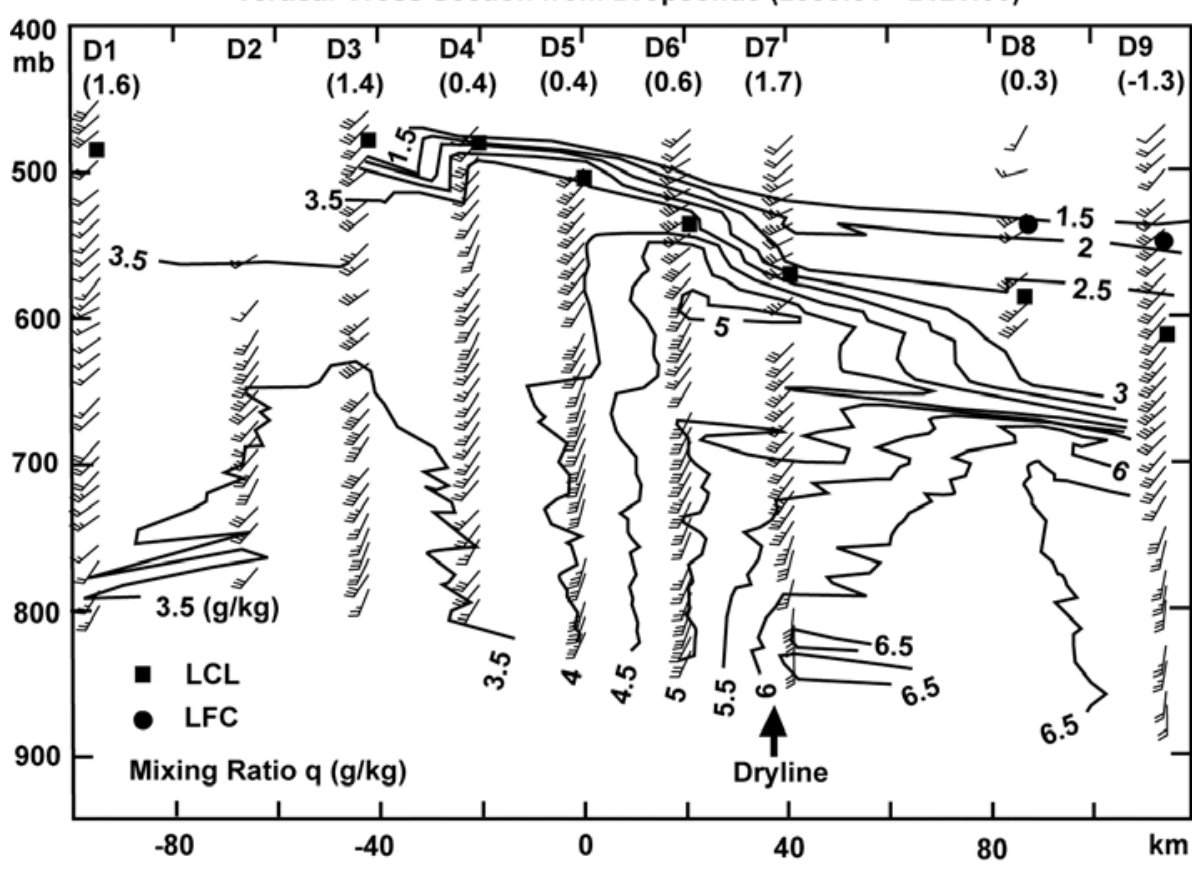

Fig. (12). Vertical cross-section of water vapor mixing ratio (solid line with contour interval of $0.5 \mathrm{~g} \mathrm{~kg}^{-1}$ ) superimposed on winds derived from Learjet dropsonde data from 2055:51 to 2121:00. Each individual drop is represented by D1 through D9. Lifted index (LI) based on each drop is printed in parenthesis near the top of the figure. Lifted condensation level (LCL) and level of free convection (LFC) are represented by black square and black dot, respectively.

ELDORA). Weak forcing, a capping inversion, and low moisture content seem to be the major reasons why no new storms were initiated near the dryline inside the IOR.
Detailed dryline case studies such as this one seems to reinforce the consensus that not until the operational observational networks are able to resolve small-scale 
kinematic and thermodynamic features on horizontal scales of a couple of kilometers, and, at the same time, numerical weather prediction models with the right physical processes could represent these features well enough, forecasting new storms at the exact time and location in the warm season will remain a challenge. Fortunately, special datasets collected by field campaigns such as IHOP_2002 are providing researchers with unprecedented data to tackle the convection initiation problem in the mean time.

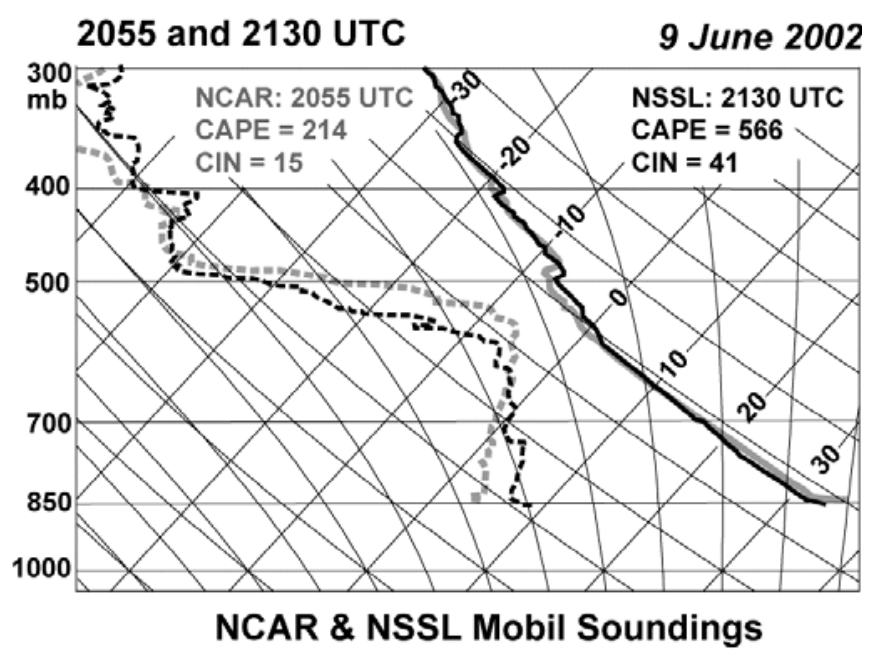

Fig. (13). Dryline soundings from NCAR and NSSL mobile sounding units. The black and dashed black lines are NSSL sounding at 2130:00; the gray and dashed gray lines are NCAR sounding at 2055:00. Both sounding positions are plotted in Fig. (2).

\section{CONFLICT OF INTEREST}

The authors confirm that this article content has no conflict of interest.

\section{ACKNOWLEDGEMENTS}

The authors would like to thank Cyrille Flamant at Institut Pierre-Simon Laplace / Servic d'Aeronomie, Paris, France and Hanne Murphey at University of California, Los Angeles for providing and processing the LEANDRE II data. Stimulating discussions with Tammy Weckwerth and Stanly Trier at NCAR and their careful review of an earlier version of this paper are greatly appreciated. LASE data, which was provided by NASA Langley was obtained from IHOP field catalog. Last but not least, comments from two anonymous reviewers that improved this manuscript substantially are gratefully acknowledged.

\section{REFERENCES}

[1] Hoch J, Markowski P. A climatology of springtime dryline position in the U.S. Great Plains region. J Clim 2005; 18: 2132-7.

[2] Ziegler CL, Hane CE. An observational study of the dryline. Mon Wea Rev 1993; 121: 1134-51.

[3] Hane CE, Ziegler CL, Bluestein HB. Investigation of the dryline and convective storms initiated along the dryline: Field experiments during COPS-91. Bull Am Meteor Soc 1993; 74: 2133-45.

[4] Bluestein HB, Crawford TM, Baldwin ME, Rabin RM. Severe thunderstorm development in relation to along-dryline variability: a case study. Mon Wea Rev 1997; 125: 231-51.
[5] Baldwin ME, Bluestein HB, Crawford TM, Rabin RM. A case study of severe storm development along a dryline within a synoptically active environment. Part I: Dryline motion and an eta model forecast. Mon Wea Rev 2001; 129: 2183-204.

[6] Rabin RM, Crawford TM, Bluestein HB, Baldwin ME. A case study of severe storm development along a dryline within a synoptically active environment: Part II: Multiple boundaries and convective initiation. Mon Wea Rev 2002; 130: 900-20.

[7] Parsons DB, Shapiro MA, Hardesty RM, Zamora RJ, Intrieri JM. The finescale structure of a west Texas dryline. Mon Wea Rev 1991; 119: 1242-58.

[8] Buban MS, Ziegler CL, Rasmussen EN, Richardson YP. The dryline on 22 May 2002 during IHOP: ground-radar and in situ data analyses of the dryline and boundary layer evolution. Mon Wea Rew 2007; 135: 2437-505.

[9] Marquis JN, Richardson YP, Wurman JM. Kinematic observations of Misocyclones along boundaries during IHOP. Mon Wea Rev 2007; 135: 1749-68.

[10] Markowski P, Hannon C, Rasmussen EN. Observations of convection initiation "failure" from the 12 June 2002 IHOP deployment. Mon Wea Rev 2006; 134: 375-405.

[11] Atkins NT, Wakimoto RM, Ziegler CL. Observations of the finescale structure of a dryline during VORTEX 95: Mon Wea Rev 1998; 126: 525-50.

[12] Weiss CC, Bluestein HB. Airborne pseudo-dual Doppler analysis of a dryline-outflow boundary intersection. Mon Wea Rev 2002;130:1207-26.

[13] Wakimoto RM, Murphey HV. Analysis of a dryline during IHOP: implications for convection initiation. Mon Wea Rev 2009; 137: 912-36.

[14] Wakimoto RM, Murphey HV. Analysis of convergence boundaries observed during IHOP. Mon Wea Rev 2010; 138: 2737-60.

[15] Cai H, Lee W-C, Weckwerth TM, Flamant C, Murphey HV. Observations of the 11 June dryline during IHOP_2002: A null case for convection initiation. Mon Wea Rev 2006; 134: 336-54.

[16] Weiss CC, Bluestein HB, Pazmany AL. Finescale radar observations of the 22 May 2002 dryline during the International H2O project (IHOP). Mon Wea Rev 2006; 134: 273-93.

[17] Miao Q, Geerts B. Fine-scale vertical structure and dynamics of some dryline boundaries observed in IHOP. Mon Wea Rev 2007; 135: 4161-84.

[18] Weckwerth TM, Parsons DB, Koch SE, et al. An overview of the International $\mathrm{H}_{2} \mathrm{O}$ Project (IHOP_2002) and some preliminary highlights. Bull Am Meteor Soc 2004; 85: 253-77.

[19] Hildebrand PH, Walther CA, Frush CL, Testud J, Baudin F. The ELDORA/ASTRAIA airborne Doppler weather radar: Goals, design, and first field tests. Proc IEEE 1994; 82: 1873-90.

[20] Lee W-C, Walther CA, Frush C, et al. The ELDORA/ASTRAIA airborne Doppler weather radar: High resolution observations from TOGA COARE. Bull Am Meteor Soc 1996; 76: 213-32.

[21] Bruneau D, Quaglia P, Flamant C, Meissonnier M, Pelon J. Airborne lidar LEANDRE II for water-vapor profiling in the troposphere. Appl Opt 2001; 40: 3450-75.

[22] Browell EV, and CoAuthor. LASE validation experiment. Advances in Atmospheric remote sensing with Lidar. In: Ansmann A, Eds, USA: Springer-Verlag 1997; pp. 289-95.

[23] Murphey HV, Wakimoto RM, Flamant C, Kingsmill DE. Dryline on 19 June 2002 during IHOP. Part I: Airborne Doppler and LEANDRE II analysis of the thinline structure and convection initiation. Mon Wea Rev 2006; 134: 406-30.

[24] Xue M, Martin WJ. A high-resolution modeling study of the 24 May 2002 dryline case during IHOP. Part I: numerical simulation and general evolution of the dryline and convection. Mon Wea Rev 2006; 134: 149-71.

[25] Wakimoto RM, Lee W-C, Bluestein HB, Liu C-H, Hildebrand PH. ELDORA observations during VORTEX 95. Bull Am Meteor Soc 1996; 77: 1465-81.

[26] Lee W-C, Dodge P, Marks FD, Hildebrand PH. Mapping of airborne Doppler radar data. J Atmos Oceanic Technol 1994; 11: $572-8$.

[27] Testud J, Hildebrand PH, Lee W-C. A procedure to correct airborne Doppler radar data for navigation errors using the echo returned from the earth's surface. J Atmos Oceanic Technol 1995; 12: $800-20$. 
[28] Oye R, Mueller C, Smith S. Software for radar translation, visualization, editing, and interpolation. Preprints. 27th Conf. on Radar Meteorology. Vail, CO: Am Meteor Soc 1995; pp. 359-61.

[29] Carbone RE, Carpenter MJ, Burghart CD. Doppler radar sampling limitations in convective storms. J Atmos Oceanic Technol 1985; 2: 357-61.

[30] Cressman GP. An operational objective analysis scheme. Mon Wea Rev 1959; 87: 367-84.

[31] Mohr CG, Miller LJ, Vaughn RL, Frank HW. The merger of mesoscale datasets into a common Cartesian format for efficient and systematic analysis. J Atmos Oceanic Technol 1986; 3: 146-61.

[32] Leise JA. A multidimensional scale-telescoped filter and data extension package. NOAA Tech. Memo 1982; ERL-82: p.11.

[33] Wakimoto RM, Cai H. Analysis of a nontornadic storm during VORTEX 95. Mon Wea Rev 2000; 129: 565-92.

[34] Barnes SL, Mesoscale objective map analysis using weighted timeseries observations. NOAA Tech Memo 1973; ERL NSSL-62: p. 60.

[35] Browell EV. Airborne remote measurements of water vapor, relative humidity, aerosol, and cloud distribution during the IHOP field experiment. Proc. Sixth Int. Symp. on Tropospheric Profiling,
Leipzig, Germany: Institute for Tropospheric Research 2003; pp.384-6.

[36] Wilson JW, Weckwerth TM, Vivekanandan J, Wakimoto RM, Russell RW. Boundary layer clear-air radar echoes: Origin of echoes and accuracy of derived winds. J Atmos Oceanic Technol 1994;11:1184-206.

[37] Geerts B, Miao Q. The use of millimeter Doppler radar echoes to estimate vertical air velocities in the fair-weather convective boundary layer. J Atmos Oceanic Technol 2005; 22: 225-46.

[38] Ziegler CL, Rasmussen EN. The initiation of moist convection at the dryline: forecasting issues from a case study perspective. Wea Forecast 1998; 13: 1106-31.

[39] Crook NA. Sensitivity of moist convection forced by boundary layer process to low-level thermodynamic fields. Mon Wea Rev 1996; 124: 1767-85.

[40] Weckwerth TM. The effect of small-scale moisture variability on thunderstorm initiation. Mon Wea Rev 2000; 128: 4017-30.

[41] Cao Z, Cho H-R. Generation of moist potential vorticity in extratropical cyclones. J Atmos Sci 1995; 52: 3263-81.

[42] Cao Z. The sting jet in a simulated extratropical cyclone. Open Atmos Sci J 2009; 3: 212-8.

(c) Cai and Lee; Licensee Bentham Open.

This is an open access article licensed under the terms of the Creative Commons Attribution Non-Commercial License (http: //creativecommons.org/licenses/by$\mathrm{nc} / 3.0 /$ ) which permits unrestricted, non-commercial use, distribution and reproduction in any medium, provided the work is properly cited. 